\title{
Acetylcholinesterase Inhibitory Potential of Various Sesquiterpene Analogues for Alzheimer's Disease Therapy
}

\author{
Ashwani Arya ${ }^{1}$, Rubal Chahal ${ }^{1}\left(\mathbb{D}\right.$, , Rekha Rao $^{2}$, Md. Habibur Rahman ${ }^{3,4}{ }^{\oplus}$, Deepak Kaushik ${ }^{1}{ }^{(0}$, \\ Muhammad Furqan Akhtar ${ }^{5}{ }^{\circ}$, Ammara Saleem ${ }^{6}{ }^{(\mathbb{C}}$, Shaden M. A. Khalifa $7, *$, Hesham R. El-Seedi ${ }^{8,9,10}$, \\ Mohamed Kamel ${ }^{11}$, Ghadeer M. Albadrani ${ }^{12}$, Mohamed M. Abdel-Daim ${ }^{13, *(1)}$ and Vineet Mittal ${ }^{1, *(1)}$
}

check for updates

Citation: Arya, A.; Chahal, R.; Rao,

R.; Rahman, M..H.; Kaushik, D.; Akhtar, M.F.; Saleem, A.; Khalifa, S.M.A.; El-Seedi, H.R.; Kamel, M.; et al. Acetylcholinesterase Inhibitory Potential of Various Sesquiterpene Analogues for Alzheimer's Disease Therapy. Biomolecules 2021, 11, 350. https://doi.org/10.3390/biom11030350

Academic Editor: Viviana di Giacomo

Received: 24 January 2021

Accepted: 22 February 2021

Published: 25 February 2021

Publisher's Note: MDPI stays neutral with regard to jurisdictional claims in published maps and institutional affiliations.

Copyright: (C) 2021 by the authors Licensee MDPI, Basel, Switzerland. This article is an open access article distributed under the terms and conditions of the Creative Commons Attribution (CC BY) license (https:/ / creativecommons.org/licenses/by/ $4.0 /)$.
1 Department of Pharmaceutical Sciences, Maharshi Dayanand University, Rohtak 124001, Haryana, India; ashwaniarya5@rediffmail.com (A.A.); imrubal1989@gmail.com (R.C.); deepkaushik1977@gmail.com (D.K.)

2 Department of Pharmaceutical Sciences, Guru Jambeshwar University of Science \& Technology, Hisar 125001, Haryana, India; rekhaline@gmail.com

3 Department of Pharmacy, Southeast University, Banani, Dhaka 1213, Bangladesh; pharmacisthabib@gmail.com

4 Department of Global Medical Science, Wonju College of Medicine, Yonsei University, Wonju 26384, Korea

5 Riphah Institute of Pharmaceutical Sciences, Riphah International University, Lahore Campus, Lahore 54000, Pakistan; furqan.pharmacist@gmail.com

6 Department of Pharmacology, Faculty of Pharmaceutical Sciences, Government College University Faisalabad, Faisalabad 38000, Pakistan; amarafurqan786@hotmail.com

7 Department of Molecular Biosciences, The Wenner-Gren Institute, Stockholm University, S-106 91 Stockholm, Sweden

8 Pharmacognosy Group, Department of Medicinal Chemistry, Uppsala University, Biomedical Centre, Box 574, 75123 Uppsala, Sweden; hesham.el-seedi@farmbio.uu.se

9 International Research Center for Food Nutrition and Safety, Jiangsu University, Zhenjiang 212013, China

10 Department of Chemistry, Faculty of Science, Menoufia University, Shebin El-Kom 32512, Egypt

11 Department of Medicine and Infectious Diseases, Faculty of Veterinary Medicine, Cairo University, Giza 12211,Egypt; m_salah@cu.edu.eg

12 Department of Biology, College of Science, Princess Nourah bint Abdulrahman University, Riyadh 11474, Saudi Arabia; gmalbadrani@pnu.edu.sa

13 Pharmacology Department, Faculty of Veterinary Medicine, Suez Canal University, Ismailia 41522, Egypt

* Correspondence: shaden.khalifa@su.se (S.M.A.K.); abdeldaim.m@vet.suez.edu.eg (M.M.A.-D.); dr.vineet123@rediffmail.com (V.M.)

Abstract: Alzheimer's disease (AD) is a gradually growing irreversible illness of the brain that almost affects every fifth person (aged > 80 years) in the world. World Health Organization (WHO) also revealed that the prevalence of this disease will enhance (upto double) significantly upto 2030. The poor cholinergic transmission at the synapse is considered to be one of the main reasons behind the progression and occurrence of this disorder. Natural inhibitors of acetylcholine (ACh) such as galanthamine and rivastigmine are used commercially in the treatmentof AD. The biomolecules such assesquiterpenes, possess a great structural diversity and are responsible for a plethora of pharmacological properties. The potential of various sesquiterpenes as anticholinesterase has been reviewed in this article. For this purpose, the various databases, mainly PubMed, Scopus, and Web of Science were investigatedwith different keywords such as "sesquiterpenes+acetylcholinesterase" and "sesquiterpenes+cholinesterase+inhibitors" in the surveyed time frame (2010-2020). A vast literature was evident in the last decade, which affirms the potential of various sesquiterpenes in the improvement of cholinergic transmission by inhibiting the AChE. After data analysis, it was found that 12 compounds out of a total of 58 sesquiterpenes were reported to possess $\mathrm{IC}_{50}<9 \mu \mathrm{M}$ and can be considered as potential candidates for the improvement of learning and memory. Sesquiterpene is an important category of terpenoids, found to possess a large spectrum of biological activities. The outcome of the review clearly states that sesquiterpenes (such as amberboin, lipidiol, etc.) from herbs could offer fresh, functional compounds for possible prevention and treatment of AD.

Keywords: cognition; coumarins; lactones; phytochemicals; neurodegeneration; acetylcholinesterase; Alzheimer's disease 


\section{Introduction}

Alzheimer's disease (AD), the most leading kind of dementia, is an age-linked neurodegenerative disease affecting approximately 24 million people around the world [1-3]. The World Health Organization (WHO) has estimated that there will be more than $100 \%$ growth of this number by the end of the year 2030. Moreover, as per the data available, it can be stated that $\mathrm{AD}$ affects almost every fifth person at the age of 80 years and up [4,5]. $\mathrm{AD}$ is a gradually growing irreversible illness of the brain and is characterized by the loss of memory, language impairment, disorientation, abstract thinking impairment, mood swings, behavior changes, loss of initiative, and trouble in performing the regular tasks on a daily basis [6,7]. The formation and deposition of the $\beta$-amyloid $(A \beta)$ plaques and accumulation of intracellular hyperphosphorylated tau proteins or neurofibrillary tangles are the main hallmarks of the AD pathophysiology [8-12]. In addition, the inflammation of neurons, stress due to free radicals, and mitochondrial dysfunction are involved in neuron degeneration and result in poor cholinergic transmission [13-15]. It has also been observed that cholinergic neurons are highly damaged in the forebrain during the progression of $\mathrm{AD}[16,17]$. An increase of acetylcholine concentration $(\mathrm{ACh})$ at the synapse by inhibiting the acetylcholinesterase (AChE) is one of the approaches to slow down the progression of $\mathrm{AD}$ [18-26]. AChE is assumed to lyse the acetylcholine at a very fast rate (up to 10,000 molecules per second). The enzyme mainly has two active sites, peripheral anionic site (PAS) and catalytic active site (CAS), for the binding of substrate, i.e., acetylcholine. The ACh temporarily sequesters to the PAS through $\pi$-cation interaction between tryptophan on enzyme surface and quaternary amine of ACh. Later, a tetrahedral intermediate forms at CAS (at the deeper gorge of enzyme) by a reaction between the oxygen atom of the acetyl group of ACh and serine-histidine-glutamate residue of the enzyme through a covalent bond (Figure 1) [27,28]. PAS of AChE also reported to have an affinity toward the peptide of $A \beta$ and the binding of this protein to enzyme promotes the amyloid fibrogenesis and converts the non-amyloidogenic form of $A \beta$ to amyloidogenic form [29]. Moreover, the conformational changes due to AChE-A $\beta$ complex formation also enhanced the metabolism of $A \beta$ and senile plaque generation [30].

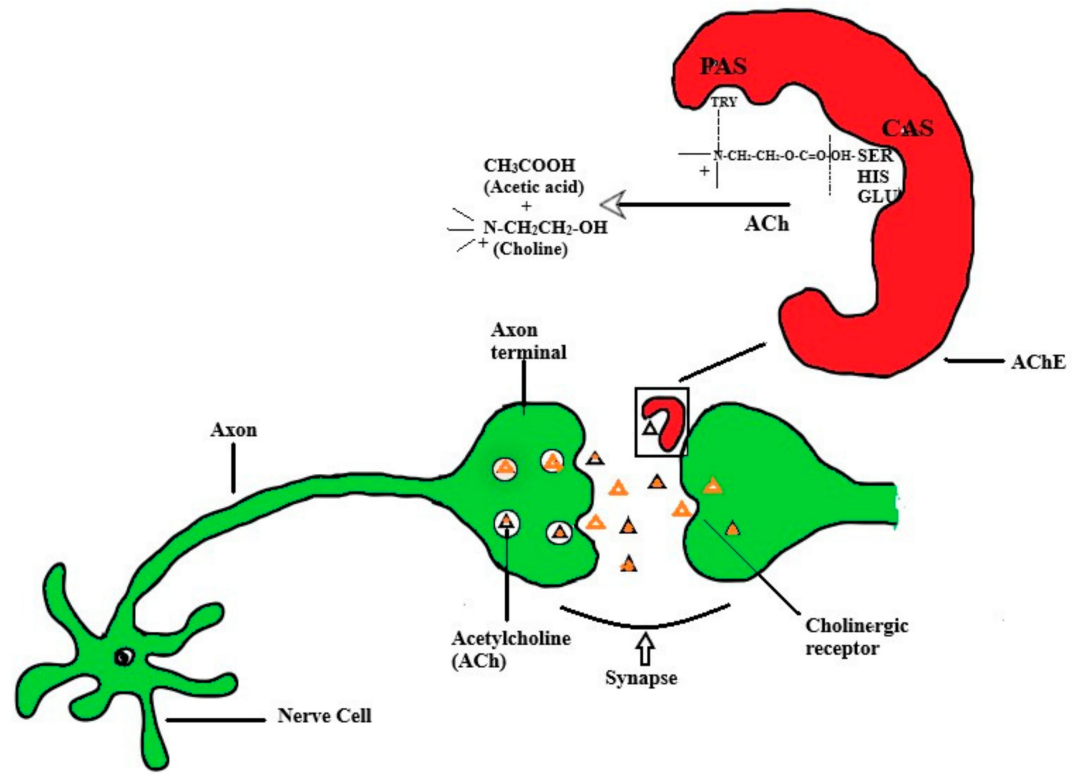

Figure 1. Acetylcholine (Ach) transmission through synapse (cholinergic transmission) and action of acetylcholinesterase (AChE) on acetylcholine. ACh: acetylcholine; AChE: acetylcholinesterase; PAS: peripheral anionic site; CAS:catalytic active site; TRY: tryptophan; SER: serine; HIS: histidine; GLU: glutamate. 
Cholinesterase inhibitors (ChEi) such as galantamine and rivastigmine mainly bind to the peripheral site in a competitive and reversible manner and spare the ACh at the synapse and thus help in the improvement of cholinergic transmission [31,32]. Rivastigmine can also hydrolyze the butyrylcholinesterase $(\mathrm{BuChE})$ present at glial cells of the temporal cortex region of the brain [33]. AChE inhibition can help in maintaining the normal neurotransmission mediated by $\mathrm{ACh}$ in a healthy brain and could prevent the occurrence or slow down the progression of $\mathrm{AD}$. However, during the late stages of $\mathrm{AD}$, the concentration of AChE decreases significantly (upto 45\%) and BuChE is enhanced (upto 40-90\%). Thus, ChEi, which are effective against both enzymes, are highly desirable in AD therapy [34]. Moreover, the reduction in substrate concentration (AChE) by these inhibitors may affect the $A \beta$ plaque formation and thus justify the use of ChEi as multi-target therapy for AD. Current drugs available for the treatment of the disease if given timely, at their best may delay the related fatal alterations but are evidently incapable of reversing the neurodegeneration process associated.

For a long time, plants have been seen as a healthcare reserve and are being used in treating and preventing human diseases and ailments. In an exploration of novel biologically active natural compounds, many traditionally used medicinal plants are being screened and evaluated for their pharmacological activities [35]. Several medicinal plants or herbs have been used to improve cognitive function, memory, and in treating neurodegenerative diseases such as AD in alternative systems of medicine [36-39]. Preclinical and clinical studies witnessed the effectiveness of the natural compounds isolated from the plants for the neuroprotective consequences through various invitro and invivo methods $[40,41]$. Furthermore, the phytoconstituents, which occur naturally, play a crucial role in treating some kind of aging-related illness [42-48]. Much research has been devoted to sesquiterpenes that own long history of usage as antimicrobial, antibacterial, antiinflammatory, cytotoxic, antiviral, antifungal, antiulcer, and anti-allergenic agents [49-57]. Sesquiterpenes are considered significant for human use and play a significant role in biological systems. [58-61]. Sesquiterpene such as nerolidol was reported to reduce the damage to biomolecules (DNA, protein, lipids) due to elevated levels of reactive oxygen species in cells [62]. In addition, the cytotoxicity of neuroblastoma cells by A $\beta$ deposition decreased significantly by sesquiterpene lactones [63]. Moreover, the active constituents of different essential oils such as farnesol, caryophyllene, and $\alpha$-humulene significantly alter the various intracellular signaling parameters of inflammation [64].

Sesquiterpenes are colorless, lipophilic terpenes found naturally in both plants and insects, holding a backbone of 15 carbons (M.F. $=\mathrm{C}_{15} \mathrm{H}_{24}$ ) with great structure diversity because of the unique and specific layering of various substituents and other functional groups around structural scaffolds [65-67]. Naturally, they occur as hydrocarbons or as oxygenated forms comprising the lactones, aldehydes, alcohols, acids, ketones, etc. Furthermore, sesquiterpenes also involve some essential oils and aromatic constituents with various pharmacological activities [68-70].

In this review article, we provide updated information about various applications of the different sesquiterpenes isolated from various plants and their role as memory enhancers by inhibiting the acetylcholinesterase (AChE).

\section{Review Methodology and Current Developments}

Herbal compounds, owning a standing as the efficient agents in numerous biological systems, currently are drawing interest for inhibiting acetylcholinesterase (AChE) activity or in the prevention of AD. The secondary metabolites of the various classes such as alkaloids, terpenoids, coumarins, flavonoids, etc. have been reported to have potent AChEinhibitory activity [71-74]. Moreover, as a biologically important class, sesquiterpenes has emerged as a potent inhibitor of $\mathrm{AChE}$ in the last decade. The potential of various sesquiterpenes as anticholinesterase has been reviewed in this article. For this purpose, the various databases, mainly PubMed, Scopus, and Web of Science were investigated with different keywords such as "sesquiterpenes+acetylcholinesterase" and "sesquiter- 
penes+cholinesterase+inhibitors" in the surveyed time frame (2010-2020) [75]. The primary screening of a plethora of plant species for their anti-Alzheimer potential could be carried out by estimating the $\mathrm{IC}_{50}$ for AChE using Ellman's method [76-80]. In the following, the role of sesquiterpenoids of different classes such as lactones, coumarins, agarofuran, and alkaloids, has been described for the possible prevention of $\mathrm{AD}$.

\subsection{Sesquiterpenoids}

Sesquiterpenoids are a group of various natural compounds and are the derivatives of a 15-C precursor called farnesyl pyrophosphate (FPP). Sesquiterpenoids are mainly confined to specialized secretory cells, laticifers, but when there is some biotic stress, and these can also be found in the vacuoles of other cells too. This diverse group is considered vital for the identity and protection of plants (response to allelopathic stimulation) and imparts various biological activities such as antimicrobial and anti-inflammatory effects [35,81-84]. Moreover, these compounds (Figure 1) can be used to hit pharmacological targets in managing the condition of $\mathrm{AD}$.

Choi et al. [85] isolated a novel seco-illudoid sesquiterpene, pterosinone(1) from the ethanolic extract of Pteridium aquilinum. Pterosinone was reported to have mild inhibitory activity against acetyl and butyl cholinesterase enzymes with $\mathrm{IC}_{50}=88 \mu \mathrm{M}$ and $73 \mu \mathrm{M}$, respectively. It was concluded from the results that sesquiterpenoids could be useful in treating AD. Chougouo et al. [51] isolated artemisinin (2) and chrysosplenetin (3) from the ethanol extract of Artemisia annua Linn. for the modulation of anticholinesterase (AChE) activity. The crude extract with artemisinin and chrysosplenetin showed the inhibition of AChE activity by $72 \%$ and $80 \%$ at $0.1 \mathrm{mg} / \mathrm{mL}$ with $\mathrm{IC}_{50}$ of $104 \mu \mathrm{M}$ and $73 \mu \mathrm{M}$.This study supported the possible use of these two compounds in neurological disorders including AD.

Jung et al. [86] isolated the Valenc-1(10), 3(4),11,(12)-trien-2-one (4) from the heartwood extract of Juniperus chinensis Linn. This compound exhibited significant butyrylcholinesterase activity with the $\mathrm{IC}_{50}=68 \mu \mathrm{M}$ when compared to the positive control, berberine $\left(\mathrm{IC}_{50}=19 \mu \mathrm{M}\right)$, and this property might be attributed to its structural configuration where two double bonds at $C_{1-10}$ and $C_{3-4}$ and $C_{11-12}$ with a ketone group at $C_{2}$ are supposed to increase the inhibitory activity.

Yang et al. [87] reported the isolation of eremophilane sesquiterpenes from the Aquilaria sinensis (Lour.) Glig and elucidated their structures by the spectroscopic procedures. Isolated compounds were found out to be 7- $\beta$ - $H$-9-(10)-ene-11,12-epoxy-8-oxoeremophilane (5) $\left(48 \pm 2 \%\right.$ inhibition at $50 \mathrm{mg} / \mathrm{mL}$ with $\left.\mathrm{IC}_{50}=275 \pm 5 \mu \mathrm{M}\right) ; 7 \alpha-H$-9(10)-ene-11,12-epoxy8-oxoeremophilane (6) with $31 \pm 1 \%$ inhibition at $50 \mathrm{mg} / \mathrm{mL}$ with $\mathrm{IC}_{50}=491 \pm 4 \mu \mathrm{M}$ ); neopetasane (7) $\left(62 \pm 1 \%\right.$ inhibition at $50 \mathrm{mg} / \mathrm{mL}$ with $\left.\mathrm{IC}_{50}=158 \pm 4 \mu \mathrm{M}\right)$.

Chen et al. [88] extracted the sesquiterpenoids from the root of Valeriana officinalis var. latifolia and investigated their AChE inhibitory activities by the modified in vitro Ellman method. It was observed that the Volvalerenic acid K (8) improved the learning and memory abilities of mice, with $\mathrm{IC}_{50}=0.16 \mu \mathrm{M}$ in vitro. The results of the study showed that, in mice (APPswe/PS1E9 double-transgenic mouse) from middle and high dose groups, the AChT (acetylcholine transferase) activity had been improved in the brain tissues, while the AChE activity was significantly decreased causing an increase in the learning memory.

Moreover, Shi et al. [89] extracted some bioactive sesquiterpenes, oxyphyllanene A, teuhetenone A, oxyphyllol B, and nootkatone from the chloroform extract of Alpinia oxyphylla fruits and evaluated for their cognitive potential. Long term exposure to chloroform extract improved the cognitive abilities while performing the behavioral tasks, increased the glutathione peroxidase (GSH-px) activities, decreased the acetylcholinesterase (AChE), malondialdehyde level (MDA), and $\beta$-amyloid $(\mathrm{A} \beta)$, and ultimately overturned the microglia activation, neuronal acidophilia degeneration, and cortex and hippocampus nuclear condensation. It was concluded that the Alpinia oxyphylla ameliorates the learning and memory deficits by attenuating the oxidative stress, regulating the activation of the microglia, and degeneration of the neuronal acidophilia to reinforce the cholinergic functions. Thus, the bioactive sesquiterpenes isolated from the chloroform extract of Alpinia oxyphylla 
may provide some therapeutic targets for the prevention and cure of AD. In addition, the ethanolic extracts of this plant have shown agood inhibitory activity of $44.49 \%$ against $\mathrm{AChE}$ at $0.1 \mathrm{mg} / \mathrm{mL}$ concentration.

The essential oils containing sesquiterpenoids in comparison to the oils containing monoterpenoids were found to be more effective inhibitors of AChE activity, and the same is the case of mixtures where it ruled by monoterpenoids showed weaker inhibition than the mixture dominated by sesquiterpenoids. Fujiwara et al. [90] evaluated the essential oil obtained from the bark of Peltophorum dasyrachis Kurz ex Bakar and the main sesquiterpenoids found were, $(+)(S)$-ar-turmerone (9) and (+)-(S)-dihydro-ar-turmerone (10). These two isolated compounds have been assessed for their AChE inhibitory activity and proved to be potent in performing their action against $\mathrm{AChE}$ in a dose-dependent manner. Di hydro derivative of turmerone is most potent with $\mathrm{IC}_{50}$ at $82 \pm 0.2 \mu \mathrm{M}$, followed by volatile oil $\left(\mathrm{IC}_{50}=83 \pm 3 \mu \mathrm{g} / \mathrm{mL}\right)$. Hence, it was concluded from the study that the different compounds isolated from the Peltophorum dasyrachis oil are effective and useful in the treatment of AD. Furthermore, the bisabolane-type sesquiterpenoid derivatives from plants, such as $(+)-(7 S, 9 S)$-ar-turmerol, (+)-(7S,9R)-ar-turmerol, (+)-(7S,9S)-dihydro-ar-turmerol, $(+)-(7 S, 9 R)$-dihydro-ar-turmerol, $(+)-(S)$-ar-curcumene, and (+)-(S)-dihydro-ar-curcumene, were synthesized which were found to exhibit the acetylcholinesterase inhibitory activity in the order hydrocarbons <alcohols $<$ ketones. The maximum activity was observed through the oxidation of the functional group at $C_{9}$ position and $C_{10}-C_{11}$ structure of single-bond moiety, (+)-(S)-dihydro-ar-turmerone. Moreover, the Turmerone was analyzed to be a competitive inhibitor of $\mathrm{AChE}$, whereas the dihydro derivative is the non-competitive inhibitor of this enzyme. Miyazawa et al. [91] investigated the leaf and stem oil of Gynura bicolor DC for AChE inhibitory potential. The leaf oil inhibited the $\mathrm{AChE}$ with $\mathrm{IC}_{50}=85 \mu \mathrm{g} / \mathrm{mL}$ ), On the other hand, stem oil showed the same inhibition with $\mathrm{IC}_{50}=92 \mu \mathrm{g} / \mathrm{mL}$. It indicated the leaf oil as a stronger inhibitor of AChE activity than the stem oil. GC-MS analysis confirmed the presence of $(E)$ - $\beta$-caryophyllene (31\%) and bicycle germacrene $(8 \%)$ as the major sesquiterpenoids from the Gynura bicolor DC leaves oil. The sesquiterpenoids in essential oil from the Gynura bicolor were found to act synergistically against AChE inhibition. Christianahet al. [92] extracted the volatile oil from the leaves of Plectranthus aegyptiacus (Forssk.) and identified thirty compounds including some sesquiterpenoids such as copaene, $\alpha$-caryophyllen, germacrene-D, and $\alpha$-cadinol with a respective concentration of $5 \%, 6 \%, 12 \%$, and $8 \%$. The oil was observed to exhibit AChE inhibitory activity with an $\mathrm{IC}_{50}=8 \pm 0.6 \mathrm{mg} / \mathrm{mL}$, which can be helpful in the treatment of AD.

Rahali et al. [93] studied the essential oil obtained from flower buds of Hertia cheirifolia and showed significant antioxidant activity along with the efficient acetylcholinesterase enzyme inhibitory activity for the prevention of AD. It was concluded that essential oil from flower buds of Hertia cheirifolia are rich in the anti-AChE activity of $1.86 \mathrm{mg}$ Eq donepezil/g of essential oil due to the presence of Germacrene D.

Similarly, the greenish-yellow color essential oil from the Salvia chionantha moderate AChE and BChE activity, i.e., $57 \pm 2 \%$ and $41 \pm 9 \%$, respectively. Cholinesterase inhibitory activity could be attributed to the presence of Germacrene D, a sesquiterpenoid in the oil. In contrast, the extract exhibited $63 \pm 0.8 \%$ activity only against BChE at the concentration of $500 \mu \mathrm{g} / \mathrm{mL}$. The results indicated the moderate potential of essential oil in the prevention of AD [94]. Moreover, the hydroalcoholic extract and the essential oil obtained from Acorus calamus (AC) rhizomes for in vitro acetylcholinesterase inhibitory activity by using Ellman's method. The $\mathrm{IC}_{50}$ values for alcoholic extract, essential oil, and two chief constituents of oil, i.e., $\beta$-asarone (11) and $\alpha$-asarone (12) were reported as $182 \pm 17 \mu \mathrm{g} / \mathrm{mL}, 11 \pm 0.8 \mu \mathrm{g} / \mathrm{mL}$, $3 \pm 0.02 \mu \mathrm{M}$, and $46 \pm 3 \mu \mathrm{M}$, respectively. It was detected that both the compounds had AChE inhibitory activity when physostigmine was taken as the standard inhibitor with an $\mathrm{IC}_{50}$ value of $0.3 \pm 0.02 \mu \mathrm{M}$. The $\beta$-asarone showed the maximum inhibition against AChE [95].

Olawuni et al. [96] extracted the essential oils of Monodora myristica and Piper nigrum Linn. seeds and evaluated them for their anti-cholinesterase and antioxidant activities. 
Both the oils showed significant AChE and BChE inhibitory activity $(p<0.05)$ in a dosedependent manner at the concentration of $416 \mu \mathrm{g} / \mathrm{mL}$. M. myristica elicited stronger inhibition for AChE and BChE with $\mathrm{IC}_{50}$ of $205 \pm 0.06 \mu \mathrm{g} / \mathrm{mL}$ and $178 \pm 0.02 \mu \mathrm{g} / \mathrm{mL}$ with $79 \%$ and $89 \%$ inhibition, whereas the P. nigrum oil inhibited the AChE (75\%) and BChE (85\%) with $\mathrm{IC}_{50}=0.3 \pm 0.02 \mu \mathrm{g} / \mathrm{mL}$ and $223 \pm 0.002 \mu \mathrm{g} / \mathrm{mL}$, respectively. The various sesquiterpenoids such as phellandrene $(18.13 \%)$, caryophyllene $(4.55 \%)$, and copaene $(2.23 \%)$ present in these oils and may be responsible for the acetylcholinesterase inhibitory potential and could be investigated in future individually.

Furthermore, the molecular docking study could also be helpful in determining the AChE inhibitory potential of a compound or essential oil. Autodock 4.2 and iGemDock 2.1 software were employed to find out the affinity of isolated essential oil from Myrciaria floribunda (H. Westex Wild) for AD target protein AChE. The oil exhibited the AChE inhibitory potential with $\mathrm{IC}_{50}=0.08 \mu \mathrm{g} / \mathrm{mL}$, and this activity is attributed to the higher binding affinity of $\delta$-cadinene and $\gamma$-cadinene (oil constituents) toward AChE as predicted by the docking score of -7.35 and -6.77 , respectively [97].

Some sesquiterpenes isolated from the plants and their worthy roles in the prevention of $\mathrm{AD}$ are also summarized in Table 1 . The structure of major sesquiterpenoids with AChE inhibitory potential is presented in Figure 2. As the AChE inhibition is one of the treatment approaches for most neurodegenerative diseases, including Alzheimer'sdisease, the essential oils that are easily inhalable and possess the AChE inhibitory potential might present a fresh vision toward the treatment of these neuronal diseases, including AD.

Table 1. Some Sesquiterpenoids that haveanticholinesterase inhibitory activity.

\begin{tabular}{|c|c|c|c|c|c|}
\hline Name of Plant & Part Used (Family) & $\begin{array}{l}\text { Solvent/Method } \\
\text { Used for Extraction }\end{array}$ & $\begin{array}{c}\text { Extract/Volatile } \\
\text { oil/Phytoconstituents }\end{array}$ & $\begin{array}{c}\text { Acetyl-Cholinesterase } \\
\text { Inhibitory/Anti-Alzheimer } \\
\text { Potential }\end{array}$ & Ref. \\
\hline $\begin{array}{l}\text { Lycopodiastrum } \\
\text { casuarinoides }\end{array}$ & $\begin{array}{l}\text { Whole plants } \\
\text { (Lycopodiaceae) }\end{array}$ & $\mathrm{EtOH}(75 \%)$ & $\begin{array}{l}\text { 7, } 9 \text {-diene }-1,4 \text {-epoxy-2 } \\
\text {-hydroxy -10 } \\
\text {-carboxylic acid [13] }\end{array}$ & $\begin{array}{l}\text { Potential inhibitory effects } \\
\text { against } A C h E \text { and BuChE with } \\
\text { an } \mathrm{IC}_{50}=9 \pm 1 \mu \mathrm{M} \text { and } \\
9 \pm 1 \mu \mathrm{M} \text { respectively }\end{array}$ & [98] \\
\hline $\begin{array}{l}\text { Lycium europaeum } \\
\text { Linn. }\end{array}$ & $\begin{array}{c}\text { Roots } \\
\text { and leaves } \\
\text { (Solanaceae) }\end{array}$ & Ethanol & Ethanolic fraction & $\begin{array}{l}\text { Ethanolic fraction of leaves (at } \\
15 \mathrm{mg} / \mathrm{kg} \text { ) exhibited effect on } \\
\text { learning and memory of } \\
\text { experimental animals with } \\
\mathrm{IC}_{50}=76 \pm 2 \mathrm{mg} / \mathrm{mL}\end{array}$ & [99] \\
\hline Aquilaria or Gyrinops & $\begin{array}{l}\text { Roots and resinous } \\
\text { heartwood } \\
\text { (Thymelaeaceae) }\end{array}$ & $95 \% \mathrm{EtOH}$ & $\begin{array}{c}\text { 2-oxoguaia- } \\
\text { 1(10),3,5,7(11), } \\
\text { 8-pentaen-12,8- } \\
\text { olide }(\mathbf{1 4}) \\
\text { (Sesquiterpenoids) } \\
4 \beta, 7 \alpha-H \text {-eremophil- } \\
\text { 9(10)-ene-12,13-diol (15) } \\
\text { (Eremophilane- } \\
\text { sesquiterpenoid) } \\
4 \beta, 5 \alpha, 7 \alpha, 8 \alpha-H-3 \beta- \\
\text { hydroxy-1(10)-ene- } \\
8,12- \\
\text { epoxy-guaia-12-one }(\mathbf{1 6}) \\
\text { (-)Gweicurculactone }(\mathbf{1 7}) \\
\text { (Guaiane- } \\
\text { sesquiterpenoid) }\end{array}$ & $\begin{array}{l}\text { The isolated compounds } \\
\text { showed the AChE inhibitory } \\
\text { activity at } 50 \mu \mathrm{g} / \mathrm{mL}\left(\left(\mathrm{IC}_{50}\right)\right. \\
\mathrm{IC}_{50}(14)=226 \mu \mathrm{M} \\
\mathrm{IC}_{50}(15)=140 \mu \mathrm{M} \\
\mathrm{IC}_{50}(16)=141 \mu \mathrm{M} \\
\mathrm{IC}_{50}(17)=202 \mu \mathrm{M} \\
\text { Tacrine }(+ \text { ve control })= \\
65 \pm 1 \mu \mathrm{g} / \mathrm{mL}\end{array}$ & [100] \\
\hline $\begin{array}{c}\text { Valeriana jatamansi } \\
\text { Jones }\end{array}$ & $\begin{array}{l}\text { Roots and rhizomes } \\
\text { (Valerianaceae) }\end{array}$ & $\mathrm{EtOH}(95 \%)$ & $\begin{array}{l}\text { Valeriananoids D (18) } \\
\text { Valeriananoids E (19) }\end{array}$ & $\begin{array}{c}\text { At the conc. of } 50 \mu \mathrm{M} \text { showed } \\
\text { AChE inhibition } \\
\text { potential activity }\end{array}$ & [101] \\
\hline
\end{tabular}


Table 1. Cont

\begin{tabular}{|c|c|c|c|c|c|}
\hline Name of Plant & Part Used (Family) & $\begin{array}{l}\text { Solvent/Method } \\
\text { Used for Extraction }\end{array}$ & $\begin{array}{c}\text { Extract/Volatile } \\
\text { oil/Phytoconstituents }\end{array}$ & $\begin{array}{c}\text { Acetyl-Cholinesterase } \\
\text { Inhibitory/Anti-Alzheimer } \\
\text { Potential }\end{array}$ & Ref. \\
\hline $\begin{array}{l}\text { Aquilaria sinensis } \\
\quad \text { (Lour.) }\end{array}$ & (Thymelaeaceae) & $\mathrm{EtOH}(95 \%)$ & $\begin{array}{c}\text { 3-oxo-7-hydroxyl } \\
\text { holosericin A }(20) \\
\text { 1,5;8,12-diepoxy-guaia- } \\
\text { 12-one (21) } \\
8 \alpha \beta \text {-octahydro-7-[1- } \\
\text { (hydroxymethyl (22) } \\
7 \alpha \text { H- } \\
\text { ethenyl]-1,8 } \alpha \text {-dimethyl } \\
\text { naphthalen-4 } \alpha(2 H) \text { - } \\
\text { o }(23) \\
\text { Neopetasane }(24)\end{array}$ & $\begin{array}{l}\text { Moderate inhibitory activities } \\
\text { against Acetylcholinesterase } \\
(\mathrm{AChE}) \text { at } 50 \mu \mathrm{g} / \mathrm{mL}, \\
\mathrm{IC}_{50}(20)=75 \mu \mathrm{M} \\
\mathrm{IC}_{50}(21)=53 \mu \mathrm{M} \\
\mathrm{IC}_{50}(22)=71 \mu \mathrm{M} \\
\mathrm{IC}_{50}(23)=87 \mu \mathrm{M} \\
\mathrm{IC}_{50}(24)=324 \mu \mathrm{M}\end{array}$ & [102] \\
\hline $\begin{array}{l}\text { Rhodomyrtus } \\
\text { tomentosa }\end{array}$ & $\begin{array}{l}\text { leaves and stems } \\
\text { (Myrtaceae) }\end{array}$ & $\begin{array}{l}\text { Petroleum ether }(\mathrm{PE}) \\
\text { extract }\end{array}$ & $\begin{array}{c}\text { (Triketone- } \\
\text { sesquiterpene } \\
\text { meroterpenoids) }\end{array}$ & $\begin{array}{l}\text { AChE inhibition rate is } 81 \% \text { at } \\
\qquad 500 \mu \mathrm{g} / \mathrm{mL})\end{array}$ & [103] \\
\hline Nelumbo nucifera & $\begin{array}{c}\text { Seeds } \\
\text { (Nelumbonaceae) }\end{array}$ & $\begin{array}{l}\text { essential oil (EO), } \\
\text { crude extract, and } \\
\text { subsequent fractions }\end{array}$ & $\begin{array}{l}\text { Essential oil mainly } \\
\text { comprised of } \\
\text { oxygenated mono and } \\
\text { sesquiterpenes }\end{array}$ & $\begin{array}{l}\text { The ethyl acetate fraction and } \\
\text { EO caused significant inhibition } \\
\text { of acetyl-cholinesterase and } \\
\text { butyryl-cholinesterase with } \\
\text { IC }_{50}=70 \pm 1,64 \pm 1 \text { and } \\
75 \pm 0.3,58 \pm 0.2, \text { respectively } \\
\text { in a dose-dependent manner. } \\
\text { EO was found to be } \\
\text { non-competitive inhibitor } \\
\text { of AChE. }\end{array}$ & [104] \\
\hline $\begin{array}{l}\text { Asteriscus maritimus } \\
\text { (Linn.) Less }\end{array}$ & $\begin{array}{l}\text { Different parts of the } \\
\text { plant (Asteraceae) }\end{array}$ & Hydrodistillation & $\begin{array}{l}\text { Oxygenated } \\
\text { sesquiterpenes of } \\
\text { Essential oil }\end{array}$ & $\begin{array}{l}\text { Among the essential oils } \\
\text { obtained from flowers, leaves, } \\
\text { and stems, the flower oil was } \\
\text { found to exhibit the highest } \\
\text { anti-acetylcholinesterase } \\
\text { activity }\left(\mathrm{IC}_{50}=95 \mu \mathrm{g} / \mathrm{mL}\right)\end{array}$ & [105] \\
\hline $\begin{array}{l}\text { Myrciaria floribunda } \\
\text { (H. West ex Willd.) }\end{array}$ & $\begin{array}{c}\text { Essential oil of fruit } \\
\text { peel } \\
\text { (Myrtaceae) }\end{array}$ & $\begin{array}{l}\text { Hydrodistillation } \\
\text { method }\end{array}$ & $\begin{array}{l}\text { Essential oil with } \\
\text { different } \\
\text { sesquiterpenes }\end{array}$ & $\begin{array}{l}\text { Essential oil exhibited the } \mathrm{AChE} \\
\text { inhibitory potential with } \mathrm{IC}_{50}= \\
(0.08 \mu \mathrm{g} / \mathrm{mL} \text { and } 23 \mu \mathrm{g} / \mathrm{mL}) \text {. } \\
\text { Neostigmine (as the standard } \\
\text { used) had an } \mathrm{IC}_{50} \text { of } 23 \mu \mathrm{g} / \mathrm{mL} \\
\text { and } 6 \mu \mathrm{g} / \mathrm{mL}) \text {. }\end{array}$ & [97] \\
\hline $\begin{array}{l}\text { Nigrospora oryzae and } \\
\text { Irpex lacteus } \\
\text { (Fungus on plant) }\end{array}$ & Culture & Acetone & Tremulanesesquiterpenes & $\begin{array}{l}\text { AChE inhibitory potential } \\
\text { concentration of } 50 \mu \mathrm{M} \text {. }\end{array}$ & [106] \\
\hline Curry Leaf & $\begin{array}{l}\text { Murraya koenigii } \\
\text { (Rutaceae) }\end{array}$ & $\begin{array}{l}\text { Hexane and } \\
\text { methanol }\end{array}$ & Essential oil & $\begin{array}{l}\text { Inhibitory activities of active } \\
\text { compounds of curry leaves } \\
\text { against } \beta \text {-secretase were found } \\
\text { and hence reported to be } \\
\text { helpful in } \\
\text { preventing dementia (AD). } \\
\text { methanolic extract ( } 70 \% \text { ) also } \\
\text { showed weak inhibitory activity } \\
\text { at } 500 \mu \mathrm{g} / \mathrm{mL} \text { against AChE }\end{array}$ & [107] \\
\hline $\begin{array}{c}\text { Teucrium persicum } \\
\text { Boiss }\end{array}$ & $\begin{array}{l}\text { Aerial parts } \\
\text { (Labiatae) }\end{array}$ & Methanol (85\%) & $\begin{array}{l}\text { Guaiasistanol (25) } \\
\text { (Guaianesesquiter- } \\
\text { penoid) }\end{array}$ & $\begin{array}{l}\text { Moderate inhibition of } \mathrm{AChE} \\
(28 \%) \text { by the isolated } \\
\text { compound. }\end{array}$ & [108] \\
\hline $\begin{array}{l}\text { Daphne holosericea } \\
\text { (Diels) Hamaya }\end{array}$ & $\begin{array}{c}\text { Dry stems } \\
\text { (Thymelaeaceae) }\end{array}$ & $\begin{array}{l}\text { Extracted with EtOH } \\
\text { (95\%) under reflux } \\
\text { three times }\end{array}$ & $\begin{array}{l}\text { Holosericin B (26) } \\
\text { (Guaiane } \\
\text { Sesquiterpenoids) }\end{array}$ & $\begin{array}{l}\text { The isolated compound showed } \\
\text { a moderateAChE Inhibitory } \\
\text { Activity with } 31 \% \text { inhibition. }\end{array}$ & [109] \\
\hline $\begin{array}{l}\text { Aquilaria sinensis } \\
\text { (Lour.) Gilg }\end{array}$ & $\begin{array}{c}\text { Heartwood } \\
\text { (Thymelaeaceae) }\end{array}$ & $\begin{array}{l}\text { Refluxed with } \\
\text { Ethanol }(95 \%)\end{array}$ & Extract & $\begin{array}{l}\text { EtOAc extract showed weak } \\
\text { AChE inhibitory activity }\end{array}$ & [110] \\
\hline $\begin{array}{l}\text { Homalomena } \\
\text { sagittifolia }\end{array}$ & $\begin{array}{l}\text { Rhizomes } \\
\text { (Araceae) }\end{array}$ & $\begin{array}{l}\text { Macerated with } \\
\text { aqueous methanol }\end{array}$ & $\begin{array}{c}1 \alpha, 4 \beta, 7 \beta- \\
\text { eudesmanetriol (27) } \\
1 \beta, 4 \beta \\
7 \beta \text {-eudesmanetriol (28) } \\
\text { (Sesquiterpenoids) }\end{array}$ & $\begin{array}{l}\text { Inhibition of } \\
\text { acetylcholinesterase with } \mathrm{IC}_{50} \\
(\mathrm{I})=26 \pm 4 ;(\mathrm{II})=250 \pm 8 \mu \mathrm{M}\end{array}$ & [111] \\
\hline
\end{tabular}


Table 1. Cont.

\begin{tabular}{|c|c|c|c|c|c|}
\hline Name of Plant & Part Used (Family) & $\begin{array}{l}\text { Solvent/Method } \\
\text { Used for Extraction }\end{array}$ & $\begin{array}{c}\text { Extract/Volatile } \\
\text { oil/Phytoconstituents }\end{array}$ & $\begin{array}{c}\text { Acetyl-Cholinesterase } \\
\text { Inhibitory/Anti-Alzheimer } \\
\text { Potential }\end{array}$ & Ref. \\
\hline Valeriana officinalis & $\begin{array}{c}\text { Roots } \\
\text { (Caprifoliaceae) }\end{array}$ & $\mathrm{EtOH}(95 \%)$ & $\begin{array}{c}\text { Spatulenol (29) } \\
\text { (Sesquiterpenoids) }\end{array}$ & $\begin{array}{l}\text { AChE was inhibited at } 100 \mathrm{mM} \\
(49 \%)\end{array}$ & [112] \\
\hline $\begin{array}{l}\text { Marsupella alpine } \\
\text { (Chinese liverwort) }\end{array}$ & $\begin{array}{l}\text { Whole plants } \\
\text { (Gymnomitriaceae) }\end{array}$ & $95 \%$ EtOH (95\%) & $\begin{array}{l}\text { Marsupellin A (30) } \\
\text { Marsupellin B (31) } \\
\text { (ent-Longipinane-Type } \\
\text { Sesquiterpenoids) }\end{array}$ & $\begin{array}{c}\text { A bioautographic TLC } \\
\text { assayforAChE inhibition was } \\
\text { performed and compound } \\
\text { showed moderate inhibition at } \\
5 \mu \mathrm{M}(28 \% \text { and } 26 \% \\
\text { respectively). }\end{array}$ & [113] \\
\hline Santalum album & $\begin{array}{l}\text { Heartwood } \\
\text { (Santalaceae) }\end{array}$ & Steam distillation & $\begin{array}{c}\alpha \text {-santalol (32), } \\
\text { Sandalwood oil (rich in } \\
\text { sesquiterpenoid } \\
\text { alcohols) } \\
\text { the major constituent of } \\
\text { the oil }\end{array}$ & $\begin{array}{l}\text { TLC-bioautographic and } \\
\text { colorimetric methods are used. } \\
\text { Essential oil is found to be a } \\
\text { potent inhibitor of tyrosinase } \\
\left.\mathrm{IC}_{50}=171 \mu \mathrm{g} / \mathrm{mL}\right) \text { and } \\
\text { cholinesterase } \\
\mathrm{IC}_{50}=5-58 \mu \mathrm{g} / \mathrm{mL} \text {. } \\
\text { For } \alpha \text {-santalol, AChE Inhibition } \\
\text { Zone }\left(\mathrm{mm}^{2}\right) \text { and BChE } \\
\text { Inhibition Zone }\left(\mathrm{mm}^{2}\right) \text { were } \\
\text { reported as } 326 \pm 19 \text { and } \\
425 \pm 27 \text { respectively. }\end{array}$ & [114] \\
\hline $\begin{array}{l}\text { Hedychium } \\
\text { gardnerianum } \\
\text { Sheppard ex } \\
\text { Ker-Gawl }\end{array}$ & $\begin{array}{l}\text { Leaf essential oil } \\
\text { (Zingiberaceae) }\end{array}$ & Hydrodistillation & $\begin{array}{c}\text { Sesquiterpene } \\
\text { hydrocarbons ( } 47.8 \text { to } \\
52.7 \% \text { ) and oxygenated } \\
\text { sesquiterpenes ( } 15.2 \text { to } \\
16.3 \% \text { ) are main } \\
\text { constituents of oil }\end{array}$ & $\begin{array}{c}\text { Microplate Assay was } \\
\text { performed and the strongest } \\
\text { inhibition against AChE was } \\
\text { displayed by the sample } \\
\text { collected from Furnas (FU) at } \\
\text { IC } 50=1 \mathrm{mg} / \mathrm{mL} \text {. }\end{array}$ & [115] \\
\hline
\end{tabular}

\subsection{Sesquiterpene Lactones (SLs)}

The sesquiterpene lactones (SLs) are biosynthesized in the medicinal plants by the oxidative transformation and cyclization of three isoprene units [1]. They constitute the largest and structurally most diverse group of secondary metabolites among several other natural compounds. SLs revealed the potential in nurturing humans as a dietary source and for health, as pharmaceutical agents, because of their efficiency in treating various types of ailments. SLs are formed through the mevalonic acid pathway of the plants. A general characteristic of SLs is the occurrence of the $\gamma$-lactone ring, which contains the $\alpha$-methylene group. The key combinations of the $\alpha$-methylene- $\gamma$-lactone comprise a few ester groups [35,116-120]. SLs are reputable across the plant kingdom that widespread in the families such as Asteraceae, Cactaceae, Euphorbiaceae, Solanaceae, Apiaceae, Acanthaceae, Amaranthaceae, Polygonaceae, Aristolochiaceae, Burseraceae, Illiciaceae, Magnoliaceae, Menispermaceae, Coriariaceae, Chloranthaceae, Lamiaceae, Lauraceae, and Winteraceae $[49,50,55]$. They are recognized for holding a wide variety of pharmacological and biological activities such as anti-fungal, anti-bacterial, anti-microbial, cytotoxic, antiviral and anti-inflammatory, etc. Moreover, according to folk remedies, SLs are active ingredients to treat influenza, inflammation, diarrhea, burns, and neuron degradation [70,117].

They are frequently isolated from the plants of the Asteraceae/Compositae family and reported to possess significant therapeutic activity. Elsebaia et al. [121] reported on amberboin (33) and lipidiol (34) as sesquiterpene lactones from the Volutaria abyssinica A. Rich (Family-Asteraceae) for the acetylcholinesterase inhibitory activity. Docking study of both compounds confirms the affinity of them towards the active sites of AChE, which indicated inhibitory activity against $\mathrm{AChE}$ at $\mathrm{IC}_{50}=0.8 \pm 0.03 \mu \mathrm{M}$ and $0.5 \pm 0.01 \mu \mathrm{M}$, respectively. Further, amberboin also inhibited the $\mathrm{BChE}_{\text {at }} \mathrm{IC}_{50}$ of $0.6 \pm 0.13 \mu \mathrm{M}$. The results clearly stated that the two isolated sesquiterpene lactones are the better inhibitors of $\mathrm{AChE}$ and $\mathrm{BChEas}$ compared to the reference, galanthamine $\left(\mathrm{IC}_{50}=3 \pm 0.2 \mu \mathrm{M}\right.$ and 


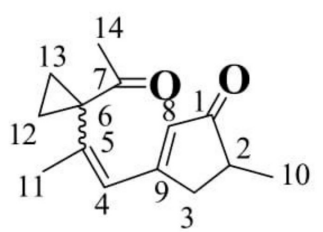

Pterosinone (1) $\left(\mathrm{IC}_{50}=88 \mu \mathrm{M}\right.$ )

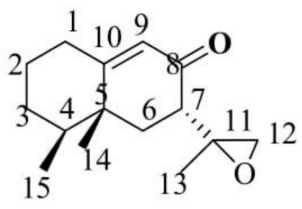

7-b-H-9-(10)-ene-11,12-e poxy-8-oxoeremophilane (5) $\left(\right.$ IC $\left._{50}=275 \mu \mathrm{M}\right)$<smiles>Cc1ccc(C(C)CC(=O)C=[14CH2])cc1</smiles>

(+)-(S)-ar-turmerone (9) $\left(\mathrm{IC}_{50}\right.$ at $\left.82 \mu \mathrm{M}\right)$

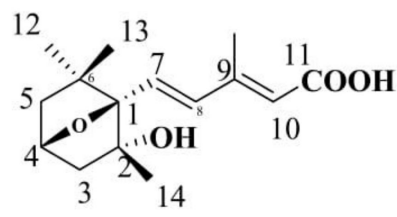

7, 9 -diene -1,4 -epoxy - 2 hydroxy -10 -carboxylic acid (13) $\left(\mathrm{IC}_{50}=9 \mu \mathrm{M}\right)$

$47 \pm 1 \mu \mathrm{M}$ for $\mathrm{AChE}$ and $\mathrm{BChE}$, respectively). In addition, the leaves of Cynara cornigera (Wild artichoke) from the Asteraceae family were extracted using methanol and seven SLs were isolated. Furthermore, a computational pharmacophore interpretation and docking design were accomplished to assess the pharmacophoric sorts and binding conformation of the isolated compounds in the AChE active site. Out of the seven metabolites, sibthorpine (35) showedAChE inhibitory activity presenting this compound to be tested for antineurodegenerative activity. It was observed from the study that sibthorpine isolated from Cynara cornigera is responsible for the inhibition of anticholinesterase $\left(\mathrm{IC}_{50}=71 \mu \mathrm{M}\right)$ activity [122].

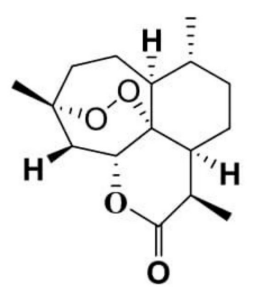

Artemisinin (2) (IC ${ }_{50}$ of $104 \mu \mathrm{M}$ )<smiles>C[C@@H]1CCCC2=CC(=O)[C@H](C3CO3)C[C@@]21C</smiles>

7a-H- 9(10)-ene-11,12epoxy-

8-oxoeremophilane (6) $\left(\mathrm{IC}_{50}=491 \mu \mathrm{M}\right)$<smiles>Cc1ccc(C(C)CC(=O)CC(C)C)cc1</smiles>

(+)-(S)-dihydro-arturmerone (10) $\left(\mathrm{IC}_{50}=83 \mu \mathrm{M}\right)$<smiles>C=C1CC(C)c2cc3c(C)c(=O)oc-3cc(C)c21</smiles>

2-oxoguaia1(10),3,5,7(11), 8 pentaen-12,8-olide (14) $\left(\mathrm{IC}_{50}=226 \mu \mathrm{M}\right)$<smiles>COc1ccc(-c2oc3cc(OC)c(OC)c(O)c3c(=O)c2OC)cc1O</smiles>

Chrysosplenetin (3) (73 $\mu \mathrm{M})$<smiles>C=C(C)[C@H]1C[C@]2(C)C(=CC1=O)CCC[C@H]2C</smiles>

Neopetasane (7) $\left(\mathrm{IC}_{50}=158 \mu \mathrm{M}\right)$<smiles>C/C=C\c1cc(OC)c(OC)cc1OC</smiles>

$\beta$-asarone (11) $\left(\mathrm{IC}_{50}=\mathbf{3} \boldsymbol{\mu \mathrm { M }}\right)$<smiles>CC1CC[C@H](C)[C@]2(C)CC(/C(=C/O)CO)CC=C12</smiles>

4b,7a-H-eremophil-9(10)ene-12,13-diol (15) $\left(\mathrm{IC}_{50}=140 \mu \mathrm{M}\right)$<smiles>C=C(C)C1CCC2=C(C)C(=O)C=C(I)C2(C)C1</smiles>

Valenc-1(10),3(4),11(12)trien-2-one (4) $\left(\mathrm{IC}_{50}=68 \mu \mathrm{M}\right)$

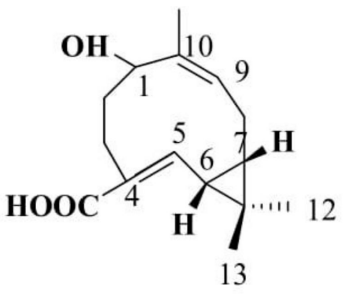

Volvalerenic acid K (8) $\left(\mathrm{IC}_{50}=0.16 \mu \mathrm{M}\right)$<smiles>C/C=C/c1cc(OC)c(OC)cc1OC</smiles>

a-asarone (12) $\left(\mathrm{IC}_{50}=46 \mu \mathrm{M}\right)$

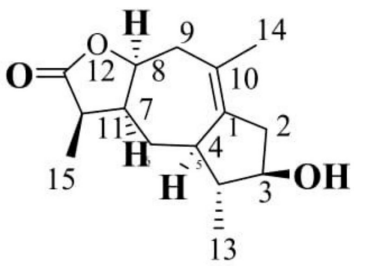

$4 \beta, 5 \alpha, 7 \alpha, 8 \alpha-H-3 \beta-h y d r o x y-$ 1(10)-ene-8,12-epoxy-guaia12-one (16) $\left(\mathrm{IC}_{50}=141 \mu \mathrm{M}\right)$

Figure 2. Cont. 
<smiles>Cc1c2c(cc3c(C)c(=O)oc-3cc1=O)[C@@H](C)CC2</smiles>

(-)Gweicurculactone (17) $\left(\mathrm{IC}_{50}=202 \mu \mathrm{M}\right)$

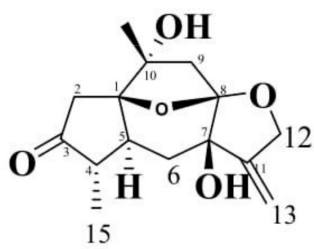

3-oxo-7-hydroxylholosericin A (20) $\left(\mathrm{IC}_{50}=75 \mu \mathrm{M}\right)$<smiles>C=C(C)[C@H]1C[C@]2(C)C(=CC1=O)CCC[C@H]2C</smiles>

Neopetasane (24) $\left(\mathrm{IC}_{50}=324 \mu \mathrm{M}\right)$<smiles>CC(C)[C@]1(O)CC[C@@H]2C(C1)[C@](C)(O)CC[C@@H]2O</smiles>

$1 \beta, 4 \beta, 7 \beta$-eudesmanetriol (28) $\left(\mathrm{IC}_{5}=250 \mu \mathrm{M}\right)$

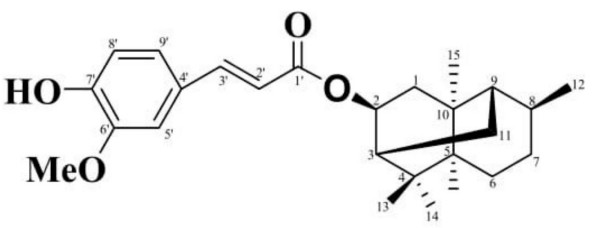

Valeriananoids D (18) $(50 \mu \mathrm{M})$

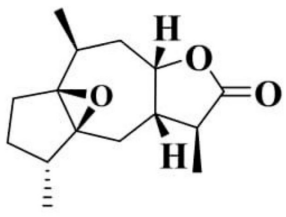

1,5;8,12-diepoxy-guaia12-one (21)
$\left(\mathrm{IC}_{50}=53 \mu \mathrm{M}\right)$

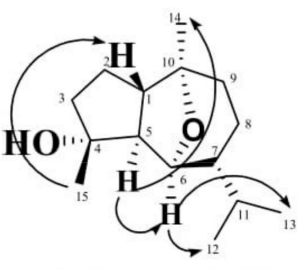

Guaiasistanol (25) (28\% inhibition)

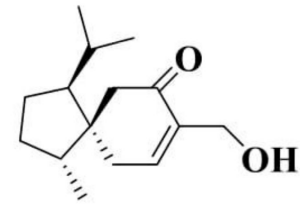

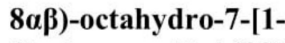
(hydroxymethyl (22) $\left(\mathrm{IC}_{50}=71 \mu \mathrm{M}\right)$

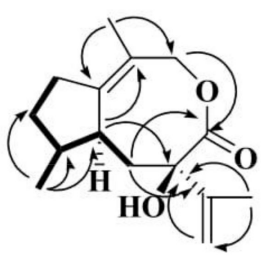

Holosericin B (26) ( $31 \%$ inhibition)

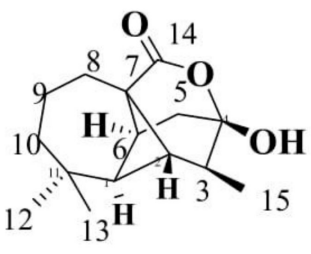

Marsupellin A (30) (28\% inhibition at $5 \mu \mathrm{M}$ )

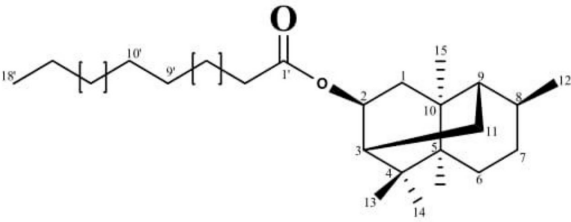

Valeriananoids E (19) $(50 \mu \mathrm{M})$<smiles>C[C@H]1CCCC2=CC(=O)C(C3(C)CO3)C[C@@]21C</smiles>

$7 \alpha \mathrm{H}$ - ethenyl]-1,8 $\alpha$ dimethylnaphthalen-4 $\alpha(2 \mathrm{H})-0$ (23) $\left(\mathrm{IC}_{50}=87 \mu \mathrm{M}\right)$

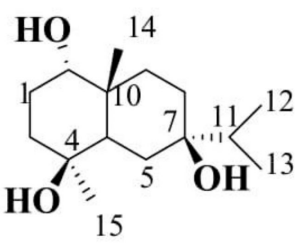

$1 \alpha, 4 \beta, 7 \beta$ - eudesmanetriol (27) $\left(\mathrm{IC}_{50}=26 \mu \mathrm{M}\right)$<smiles>C[C@H]1CCCC23CO[C@H](C)[C@H]2[C@H]1[C@H]3C</smiles>

Marsupellin B (31) (26\% inhibition at $5 \mu \mathrm{M})$<smiles>C=C1CCC2C(C3C1CCC3(O)I)C2(C)C</smiles>

Spatulenol (29) (49\% inhibition at 100 mM )

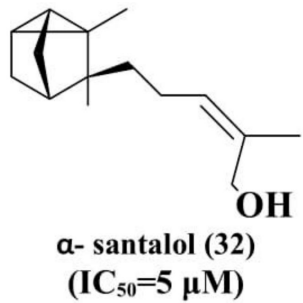

Figure 2. Various sesquiterpenoids moieties with $\mathrm{AChE} / \mathrm{BChE}$ inhibitory potential.

Hajimehdipooret al. [123] extracted the SLs from the Inula oculus-christi and I. aucheriana (Family-Compositae) and evaluated their capability of inhibiting AChE activity by using the Ellman assay method. It was observed that out of the three evaluated compounds, the Gaillardin (36) was the most versatile secondary metabolites ( $\mathrm{IC}_{50}$ for AChE $729 \mu \mathrm{M}$ ) present in the plants and can be investigated for further AD studies. 
Ibrahim et al. [124] isolated four sesquiterpene lactones from Amberboa ramosa (FamilyAsteraceae) using the ethyl acetate soluble fraction and tested them against $\mathrm{AChE}$ and BChE. Their $\mathrm{IC}_{50}(\mu \mathrm{M})$ for $\mathrm{AChE}$ inhibition was reported as $17 \pm 0.01,9 \pm 0.2,0.9 \pm 0.02$ and $1 \pm 0.08$ for sesquiterpene lactones Amberin (37), Amberbin-A (38), Amberbin-B (39), and Amberbin-C (40), respectively, and for BChE inhibition was at $3 \pm 0.02$ (Amberin), $5 \pm 0.2$ (Amberin-A), $2.5 \pm 0.2$ (Amberin-B) and $18 \pm 0.05$ (Amberin-C). This study showed that all the SLs. isolated from Amberboa ramosa might be effective against AChE and BChE enzymes and could be used as remarkable lead molecules in the drug development for the prevention of AD. Patel and Amin [125] extracted the 7-hydroxy frullanolide (41), a sesquiterpene lactone, from the flower heads of Sphaeranthus indicus (Family-Asteraceae) and carried out in vitro anticholinesterase activity of several extracts. Petroleum ether fraction was found to be loaded with SLs (about $80 \%$ ), accounting for its anti-AChE activity. It was observed that petroleum ether fraction was the only portion with $\mathrm{AChE}$ inhibitory potential with an $\mathrm{IC}_{50}$ of $37 \mathrm{mg} / \mathrm{mL}$ and the extract at a dose of $10 \mathrm{mg} / \mathrm{kg}$, per orally. in mice considerably inverted the cognitive damages caused through the passive avoidance test $(p<0.05)$.

In the light of the above-cited examples, various SLs (Figure 3) seem to be promising acetylcholinesterase inhibitors and helpful in improving the equilibrium between the excitatory and inhibitory potential of neurons and thus can be used in the possible management of $\mathrm{AD}$.<smiles>CC1C(=O)O[C@H]2C(=O)C[C@H]1C[C@H]2O</smiles>

Amberboin (33) $\left(\mathrm{IC}_{50}=0.8 \mu \mathrm{M}\right)$

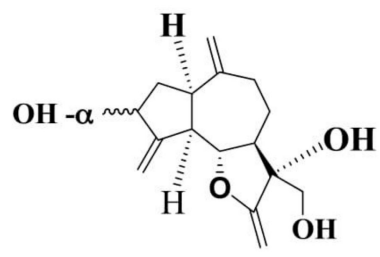

Sibthorpine (35) $\left(\mathrm{IC}_{50}=71 \mu \mathrm{M}\right)$

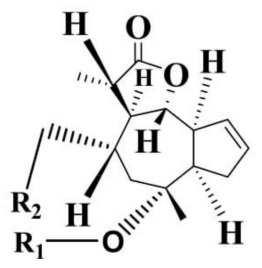

Amberin [ R1 = Acetyl R2= D-glucose $](37)$ (IC I0 $=17 \mu \mathrm{M}$ )

Amberbin-A [R1 $=$ H R2 $=$ Acetyl $](38)$ $\left(\mathrm{IC}_{50}=9 \mu \mathrm{M}\right)$

Amberbin-B [R1=D-glucose R2= Acetyl] (39) $\left(\mathrm{IC}_{50}=0.9 \mu \mathrm{M}\right)$

Amberbin- C $[$ R1 $=$ Glecerol R2 = Acetyl $]$ (40) $\left(\mathrm{IC}_{50}=1 \mu \mathrm{M}\right)$<smiles>C=C1C[C@H](O)C2C(C)C(=O)OC2C2C1CC(O)C2C</smiles>

Lipidiol (34)

$\left(\right.$ IC $\left._{50}=0.5 \mu \mathrm{M}\right)$<smiles>C=C1C(=O)C[C@H]2C=C[C@H](O)[C@H](O)[C@H]1[C@H]2C(C)C</smiles>

Gaillardin (36)

$($ IC50 $=729 \mu \mathrm{M})$<smiles>CC1=C2[C@@H]3OCC[C@@]3(O)CC[C@]2(C)CCC1</smiles>

7-hydroxy frullanolide (41)

$\left(\mathrm{IC}_{50}\right.$ of $\left.536 \mu \mathrm{M}\right)$

Figure 3. Sesquiterpene lactones/their derivatives for AChE inhibition. 


\subsection{Miscellaneous Sesquiterpenes}

The role of sesquiterpenes of different categories such as coumarins, agarofuran, and alkaloids in the $\mathrm{AD}$ are described as follows:

\subsubsection{Sesquiterpene Coumarins}

Sesquiterpene coumarins (SC) is an interesting family of natural products, isolated mainly from Ferula genus in which through an ether linkage coumarin moiety mainly umbelliferone (7-hydroxycoumarin) and sometimes isofraxidin (7-hydroxy-6,8-dimethoxycoumarin) or scopoletin (7-hydroxy-6-methoxycoumarin) is connected to the $\mathrm{C}_{15}$ terpene moiety. The prenyl-furocoumarin-type sesquiterpenoids represent a different cluster in sesquiterpene coumarins, whereby the involvement of $C_{3}$, coumarin, and $C_{15}$ moiety are connected through the $\mathrm{C}-\mathrm{C}$ bond. SC is set up in numerous medicinal plants belonging to various other families such as Asteraceae, Rutaceae, Apiaceae, etc. [44,126-128]. Ferula genus always has been a matter of study and controversy because of its wide chemical variation in different types of plants from different locations. For illustration purposes, investigations of Ferulacommunis population from Sardinia revealed that two chemotypes of the plant from this region have different characteristics. One of the chemotypes contained prenylated 4-hydroxycoumarins, which are toxic while the second one demonstrated therapeutic activity because of the presence of the SC ethers $[127,128]$.

Guvenalpet al. [129] isolated the sesquiterpene coumarins such as umbelliprenin (42) and feselol (43) from the chloroform extract of Heptapteracilicica fruits. The compounds showed potential inhibitory activity against $\mathrm{AChE}\left(\mathrm{IC}_{50}=6 \pm 0.03 \mu \mathrm{M}\right.$ and $1 \pm 0.01 \mu \mathrm{M}$, respectively) and $\mathrm{BChE}\left(\mathrm{IC}_{50}=10 \pm 0.24 \mu \mathrm{M}\right.$ and $1 \pm 0.19 \mu \mathrm{M}$, respectively) and established the plant as an emerging source in $\mathrm{AD}$ treatment. Other studies have also been conducted in the past, supporting the anticholinesterase activity of these compounds.

\subsubsection{Dihydro- $\beta$-AgarofuranSesquiterpenes}

Tricyclic 5,11-epoxy-5- $\beta, 10$ - $\alpha$-eudesman-4-(14)-ene is the basic moiety accounting for this structurally diverse class, dihydro- $\beta$-agarofuransesquiterpenes. These compounds mainly belong to the family Celastraceae and are held responsible for many pharmacological activities such as their anti-HIV, cytotoxic, insecticidal, anti-feedant, and immunosuppressive properties, etc. A lot of therapeutic significance of medicinal plants has been recognized from the family of more oxygenated sesquiterpenoids, which are depending on a tricyclic dihydroagarofuran skeleton type. Studies conducted on the agarofuran compounds with a motive of developing some new $\mathrm{AChE}$ inhibitors have achieved great success in the past years and suggested that agarofuran compounds may act as lead compounds in the designing of new, less toxic, and highly selective anticholinesterase agents along with some other positive therapeutic effects [130,131].

Alacronet al. [131] isolated constituents with agarofuran skeleton (epoxyeudesmane) from the Maytenusdisticha and Euonymus japonicas aerial parts and seeds. All dihydro agarofuranoid sesquiterpenes such as, $1-\alpha, 6-\beta, 8-\alpha$-Triacetoxy-9- $\beta$-furoyloxy- $\beta$-agarofuran (44), 1- $\alpha$-Hydroxy-6- $\beta, 8$ - $\alpha$-diacetoxy-9- $\beta$-furoyloxy- $\beta$-agarofuran (45), 1- $\alpha, 6-\beta$-Diacetoxy- $8-\alpha$ hydroxy-9- $\beta$-furoyloxy- $\beta$-agarofuran (46), 1- $\alpha$-Acetoxy-6- $\beta, 8$ - $\alpha$-dihydroxy-9- $\beta$-furoyloxy$\beta$ agarofuran (47), 1- $\alpha, 2-\alpha, 6-\beta, 8-\alpha, 15-P e n t a a c e t o x y-9-\beta$-benzoyloxy- $\beta$-agarofuran(48), 1$\alpha, 2-\alpha, 3 \beta, 15$-Tetraacetoxy-6- $\beta, 9-\beta$-dibenzoyl-8-oxo- $\beta$-agarofuran(49), 1- $\alpha, 6-\beta, 15$-Triacetoxy9-benzoyloxy- $\beta$-agarofuran (50), 2- $\alpha, 3-\beta, 6-\beta, 8-\alpha, 15-P e n t a a c e t o x y-1-\alpha, 9-\beta$-benzoyloxy- $\beta$ agarofuran (51) were found to exhibit anti-acetylcholinesterase (AChE) activity. The compounds isolated from seeds of $M$. disticha and E. japonicas showed the AChE inhibitory activity with the $\mathrm{IC}_{50}(\mathrm{mg} / \mathrm{mL})$ of $0.1 \pm 0.01(44), 0.3 \pm 0.02(45), 0.1 \pm 0.004(46), 0.1 \pm 0.006$ (47), $0.1 \pm 0.002$ (48), $0.3 \pm 0.015$ (49), $0.4 \pm 0.006$ (50) and $0.4 \pm 0.009$ for the compound (51). Based on these data, the majority of the compounds indicated acceptable inhibitory activity in the submicromolar concentrations ranges, i.e., $0.1-0.4 \mathrm{mg} / \mathrm{mL}$ on comparison with the reference drug, galanthamine. On the other hand, these compounds are found to be selective inhibitors for AChE activity. Alarcon et al. [132] extracted the dihydro- $\beta$ - 
agarofuran sesquiterpene from the Maytenus disticha (aerial parts) and Maytenus boaria (seeds) of Celastraceae family. The compounds and their AChE inhibitory potential of $\left(\mathrm{IC}_{50}\right.$ in $\mathrm{mg} / \mathrm{mL}$ ) were found to be, $1-\alpha, 2-\alpha, 6,8 \alpha$-tetraacetoxy-9-benzoyloxy-15-hydroxy agarofuran (52) (0.1 \pm 0.01$), 1-\alpha, 2-\alpha, 6-\beta$-triacetoxy-9- $\beta$-benzoyloxy-15-hydroxy- $\beta$ agarofuran (53) $(0.1 \pm 0.01), 1-\alpha, 2-\alpha, 6-\beta$-triacetoxy-9- $\beta$-benzoyloxy-8- $\alpha, 15$-dihydroxy- $\beta$-agarofuran (54) $(0.3 \pm 0.02), 1-\alpha, 2-\alpha, 6-\beta, 8-\alpha, 15$-pentaacetoxy-9- $\beta$-benzoyloxy- $\beta$-agarofuran (55) $(0.2 \pm 0.003)$, 1 - $\alpha$-acetoxy-6- $\beta$, 9- $\beta$-difuroyloxy-4- $\beta$-hydroxy- $\beta$-agarofuran (56) (0.4 \pm 0.04$)$, and $6-\beta, 8-$ $\alpha$-diacetoxy-9- $\beta$-furoyloxy-1- $\alpha$-hydroxy- $\beta$-agarofuran(57) $(0.3 \pm 0.02)$. Therefore, it was observed that the agarofuran compounds isolated from the aerial parts of Maytenus disticha and seeds of Maytenus boaria have good signs for their further use in the treatment of AD or as acetylcholinesterase inhibitors.

It was concluded from the above-cited examples that the selective inhibitory potential of agarofuran compounds for $\mathrm{AChE}$ and low toxicity might lead to the development of novel therapeutic agents for possible AD management.

\subsubsection{Sesquiterpene Alkaloids}

In the last decades, investigations to find out some natural sources for acetylcholinesterase inhibitory activity have been fastened, and the good thing is that the scientists are achieving progressive results as most of the alkaloids are capable ofimproving cognitive deficits. Among the various constituents that evolved with AChE inhibitory activity, alkaloids type sesquiterpenes have snatched a crowning position [38]. Some of the accessible information about sesquiterpene alkaloids, presented them as the lead molecules of the future prevention of $\mathrm{AD}$, as pinpointed here $[133,134]$.

Gul et al. [133] extracted a broad neuroprotective sesquiterpene alkaloid, Huperzine-A (58) from the Chinese herb, Huperia serrata. This natural compound showed reversible AChE inhibitory activity $\left(\mathrm{IC}_{50}=22 \mu \mathrm{M}\right)$ and can enhance cognitive abilities and task switching functions rapidly in people suffering from $\mathrm{AD}$. One more study suggested that this compound may be beneficial in treating hypoxic-ischemic encephalopathy in neonates. Huperzine-A has been proved to lessen the glutamate-induced cytotoxicity by its antagonizing action on cerebral N-methyl-D-aspartate (NMDA) receptors, and this mechanism of antagonism is one plausible justification for its neuroprotection property [134-137]. Coupled with these studies, Huang et al. [3] investigation about the compound provided a marked base for the establishment of this compound as a reversible, selective, potent, and finely tolerated inhibitor of acetylcholinesterase which can considerably improve the memory and learning deficit in the persons suffering from Alzheimer's disease.

The above discussed sesquiterpenes, from plants or natural sources, have been demonstrated as potent inhibitors of acetylcholinesterase. Figure 4 indicates the structure of miscellaneous sesquiterpenes found effective against acetylcholinesterase. 

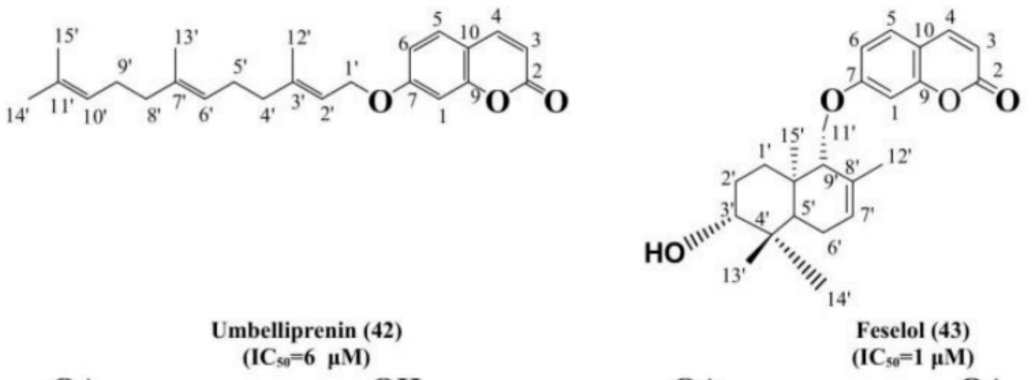

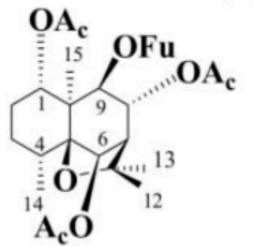

$1-\alpha, 6-\beta, 8-\alpha-$ Triacetoxy-9- $\beta$ furoyloxy- $\beta$-agarofuran (44) $\left(\mathrm{IC}_{50}=0.1 \mathrm{mM}\right)$

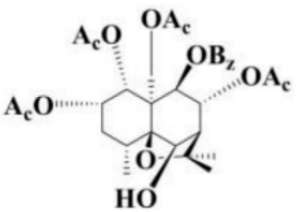

1- $\alpha$-Acetoxy-6- $\beta, 8-\alpha-$ dihydroxy-9- $\beta$-furoyloxy- $\beta$ agarofuran (48) $\left(\mathrm{IC}_{\mathrm{so}}=0.01\right.$ $\mathrm{mM}$ )

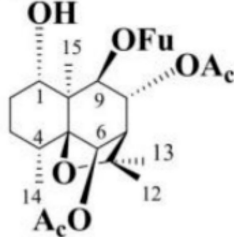

1- $\alpha-H y d r o x y-6-\beta, 8-\alpha-$ diacetoxy-9- $\beta$-furoyloxy- $\beta$ agarofuran $(45)\left(\mathrm{IC}_{50}=0.3\right.$ $\mathrm{mM}$ )

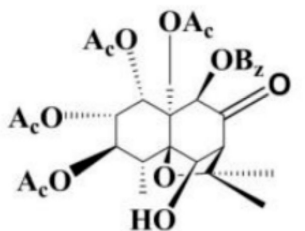

$1-\alpha, 2-\alpha, 3 \beta, 15$ Tetraacetoxy6- $\beta, 9-\beta$-dibenzoyl-8-0x0- $\beta$ agarofuran (49) $\left(\mathrm{IC}_{s_{0}}=0.3\right.$ $\mathrm{mM}$ )

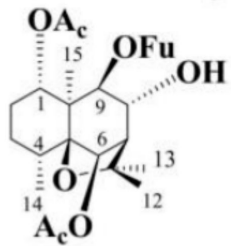

1- $\alpha, 6-\beta-D i a c e t o x y-8-\alpha$ hydroxy-9- $\beta$-furoyloxy$\beta$-agarofuran (46) (IC 50 $=0.1 \mathrm{mM}$ )

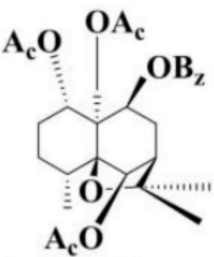

1-a,6-b,15-Triacetoxy-9benzoyloxy-bagarofuran (50) $\left(\mathrm{IC}_{50}=\right.$ $0.4 \mathrm{mM}$ )

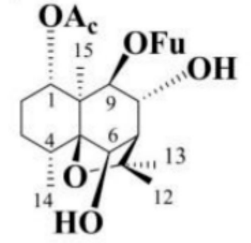

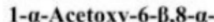
dihydroxy-9- $\beta$-furoyloxy- $\beta$ agarofuran (47) $\left(\mathrm{IC}_{50}=\right.$ $0.01 \mathrm{mM}$ )

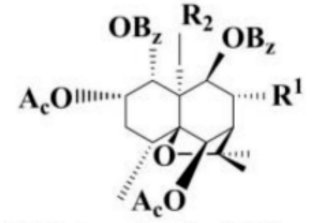

2- $\alpha, 3-\beta, 6-\beta, 8-\alpha, 15-P e n t a a c e t o x y-1-\alpha, 9-\beta-b e n z o y l o x y-\beta-$ agarofuran (52) $\left(\mathrm{IC}_{50}=0.1 \mathrm{mM}\right)$ 1- $\alpha, 2-\alpha, 6,8 \alpha$-tetraacetoxy-9-benzoyloxy-15-hydroxy agarofuran $\left[\mathbf{R}^{1}=\mathrm{OA}_{\epsilon} \quad \mathbf{R}^{2}=\mathrm{OH}\right] \quad(53)$ $\left(\mathrm{IC}_{\mathrm{s}_{0}}=0.1 \mathrm{mM}\right)$

1- $\alpha, 2-\alpha, 6-\beta$-triacetoxy-9- $\beta$-benzoyloxy-8- $\alpha, 15$ dihydroxy- $\beta$-agarofuran $\left[\mathrm{R}^{1}=\mathrm{OH} \quad \mathrm{R}^{2}=\mathrm{OH}\right](54)$ $\left(\mathrm{IC}_{50}=0.3 \mathrm{mM}\right)$

1- $\alpha, 2-\alpha, 6-\beta, 8-\alpha, 15-p e n t a a c e t o x y-9-\beta$-benzoyloxy- $\beta$ agarofuran $\left|\mathbf{R}^{1}=\mathrm{OA}_{\mathrm{c}} \quad \mathbf{R}^{2}=\mathrm{OA}_{\mathrm{c}}\right|$ $\left(\mathrm{IC}_{50}=0.2 \mathrm{mM}\right)$

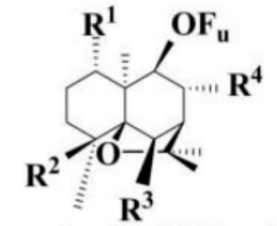

1- $\alpha$-acetoxy-6- $\beta, 9-\beta$-difuroyloxy-4- $\beta$ hydroxy- $\beta$-agarofuran $\left[\mathbf{R}^{1}=\mathbf{O A c} \mathbf{R}^{2}=\right.$ OH $\quad R^{3}=$ OFu $\left.\quad R^{4}=H\right](56)$

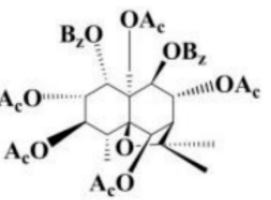

1- $\alpha, 6-\beta, 15-T$ riacetoxy-9. benzoyloxy- $\beta$-agarofuran (51) $\left(\mathrm{IC}_{50}=0.4 \mathrm{mM}\right)$

$$
\mathrm{IC}_{50}=0.4 \mathrm{mM} \text { ) }
$$

6- $\beta, 8-\alpha$-diacetoxy-9- $\beta$-furoyloxy-1- $\alpha$ hydroxy- $\beta$-agarofuran $\left[R^{1}=\right.$ OAc $R^{2}=$

H $\mathbf{R}^{3}=$ OAc $\mathbf{R}^{4}=$ OAc] $(57)$ $\left(\mathrm{IC}_{50}=0.3 \mathrm{mM}\right)$

Figure 4. Structure of miscellaneous sesquiterpenes found effective against acetylcholinesterase.

\section{Sesquiterpenes for Alternate AD Targets}

The pathophysiology of AD is very much complicated and a single target therapy is not beneficial for the management of this neurodegenerative disease. The various sesquiterpenes could also be employed for the multiple targets such as reduction in $A \beta$ plaque, neuroinflammation, oxidative stress and alteration in GABAergic transmission.

Qi et al. [138] investigated the waste produced of Stigma maydis (maize) industry and isolated macrocarpene type sesquiterpenes compounds, namely Stigmene A and Stigmene $B$, and screened for their $A \beta$ aggregation inhibitory activities. It was observed that $(\%)$ decrease in $A \beta$ aggregation was found more in the case of Stigmene A $(82.9 \pm 2.52 \%)$ and Stigmene B $(70.1 \pm 3.01 \%)$ when compared against a positive control, $(69.8 \pm 1.55 \%)$. The result of the study suggested that the presence of these two valuable compounds made Stigma maydis crop waste a promising source for the pharmaceutical firms involved in the manufacturing/research of formulations for neurological disorders such as AD. 
Huangaet al. [139] studied the memory-enhancing property of the Ginkgo biloba (Family-Ginkgoaceae) leaf extract. The chief constituent of the extract, bilobalide, a sesquiterpene trilactone, was found to deter the straight action of gamma-aminobutyric acid (GABA) receptors. Dueto this property, the constituent tends to have a vibrant role in treating cognitive dysfunction in dementia. The bilobalide $\mathrm{IC}_{50}(4.6 \pm 0.5 \mu \mathrm{M})$ was reported as comparable to conventional antagonists of GABA receptors, picrotoxinin $(2.4 \pm 0.5 \mu \mathrm{M})$ and bicuculline $(2.0 \pm 0.1 \mu \mathrm{M})$ at $\alpha_{1} \beta_{2} \gamma_{2 \mathrm{~L}} \mathrm{GABA}_{\mathrm{A}}$ receptors against GABA neurotransmitter. Bilobalide amplified the levels of GABA in the cerebral cortex and hippocampus of mice; in addition, bilobalide also enhanced the neuronal excitability in hippocampus sites through the blockade of GABAergic neurotransmission, which is directly correlated with the learning and memory motions. The potency level of bilobalide decreased with increasing GABA concentrations indicating a module of competitive antagonism.

Amoahet al. [140] studied the SLs and sesquiterpene alcohol (SA) isolated from the Hedyosmum brasiliense (Family-Chloranthaceae) for anti-inflammatory and anti-oxidative activities. During the investigation, it was observed that aromadendrane- $4 \beta, 10 \alpha$-diol (ARD), 13-hydroxy-8,9-dehydroshizukanolide (HDS) and podoandin (PDA), efficiently ameliorated the $\mathrm{A} \beta$ peptide-induced memory impairment in models of the passive avoidance task $(p<0.05)$. The above-stated SLs compounds showed a considerable effect on oxidative stress and enhanced the memory power in animals that received $A \beta-42$ infusion. However, the neuroprotective effects possessed by these tested compounds were found more correlated to the existence of the guaiane ring in comparison to the presence of the lactone ring for which mechanism of action is described by Michael-type nucleophilic addition. This study confirmed that ARD, HDS, and PDA, the constituents of H. brasiliense, are efficient in inhibiting the cognitive deficits of animals and may be used in treating AD.

Neuroinflammation is one of the major factors of $\mathrm{AD}$ and other disorders related to cholinergic transmission. It can be attenuated by reducing the expression of NF- $\mathrm{kB}-\mathrm{p} 65$ via NLRP3 pathways. Thus targeting the transcription factor (NF- $k \beta p 65)$ could be the novel approach for the treatment of AD. This factor upregulates the expression of inflammatory cytokines and genes related to oxidative stress and BACE-1 (B-site APP Cleaving Enzyme), responsible for the production of $\beta$-amyloid [141,142]. Wanga et al. [143] isolated the nootkatone from petroleum ether extract of Alpiniae oxyphyllae Fructus and demonstrated that it could improve the lipopolysaccharide-induced memory and learning impairment, which was proposed to be associated with its attenuating neuroinflammatory activity through the expression of transcription factor NF-kB-p65. Nootkatone at $10 \mathrm{mg} / \mathrm{kg}$ showed significant improvement in neuroprotective potential on evaluation through various behavioral models (Morris water maze and Y maze). This study indicated that the compound, nootkatone, might play a role as a potent therapeutic agent in treating AD and neuroinflammation via improvement in cholinergic transmission, clearing amyloid- $\beta$-peptide, and reducing oxidative stress.

In addition, ambrosin, another sesquiterpene lactone, was isolated from the ethanolic extract of Ambrosia maritima (Family-Asteraceae). Although it was not evaluated for the AChE inhibitory potential but found to reduce the expression of NF- $\mathrm{\beta} \beta \mathrm{p} 65$, transcription factor, in experimental mice. Halting the expression of this factor could reduce the production of $\beta$-amyloid $(A \beta)$, which results in enhancement of cholinergic transmission at the synapse. Moreover, ambrosin at $10 \mathrm{mg} / \mathrm{kg}$ dose also reduces the detrimental effect of lipopolysaccharide on the learning and memory potential of mice [144].

Hence ambrosin and nootkatone, as novel sesquiterpenes, could significantly reduce the expression of this transcription factor (NF- $\mathrm{\beta} \beta \mathrm{p} 65)$ in experimental groups.

The Jatanolides, Jatamansone, and Jatamansic acid are the main sesquiterpene alkaloids isolated from the Nardostachys jatamansi, which are helpful in cognitive disorders as they improve the learning and memory supremacy of a person $[145,146]$. Joshi and Parle [146] studied the ethanolic extract of Nardostachys jatmansi in mice to evaluate its memory enhancing property and found it capable of significantly improving the learning and memory at a dose of $200 \mathrm{mg} / \mathrm{kg}$ and also reversed the scopolamine $(0.4 \mathrm{mg} / \mathrm{kg}$, 
i.p.) and diazepam (1 mg/ $\mathrm{kg}$, i.p.) induced amnesia. It was concluded that memory enhancement could be a result of the facilitation of cholinergic transmission in the brain becausethe extract showed potential against scopolamine-induced impairment. Furthermore, the extract also reversed the aging-related amnesia proving it as a beneficial memory restorative constituent in elderly individuals with dementia. The mechanism of action can be credited to its anti-oxidative property. The neuroprotective, anti-cerebral ischemic and antioxidative properties of various Jatanolides present in the plant may be the reason for its memory-enhancing activity.

The above-cited compounds may potentially be used as moieties in the building of a better multi-target anti-AD drug for possible prevention and treatment of AD.

\section{Market Formulations to Alleviate AD Symptoms}

There are various formulations available in the market that claim to alleviate the symptoms of AD. However, in reality, only a few marketed drugs clinically improve cholinergic transmission by inhibiting the cholinesterase enzyme. Moreover, the literature review reveals that only a single cholinesterase inhibitor is in Phase II and Phase III clinical trials, for AD management $[147,148]$. Moreover, Huperzine A is the only sesquiterpene alkaloid that is clinically established as an AChE inhibitor and receivedthe approval of USFDA to manage AD. In addition, the large number of formulations having extracts of Ginkgo biloba and Nardostachys jatamansi are mentioned in Table 2 and mainly prescribed as a nutraceutical for delaying symptoms (such as amnesia) of AD. The extracts of these herbs are reported to contain sesquiterpenes such asBilabolide and Jatanolides/Jatamansone as main ingredients. Preclinical studies prove the neuroprotective role of these herbs due to reduction in neuronal damage by free radicals and restoration of calcium homeostasis [41]. Hence, this could be the possible rationale for the inclusion of these herbs as food supplements for $\mathrm{AD}$.

Table 2. Marketed formulation of the sesquiterpenes used for memory-enhancing activity.

\begin{tabular}{|c|c|c|c|}
\hline Phytoconstituents & Marketed Formulation & Dose and Form & Manufacturing Company \\
\hline Huperzine A & $\begin{array}{l}\text { Huperzine A Dietary } \\
\text { supplements }\end{array}$ & 200 MCG 120 tablets & $\begin{array}{l}\text { National INC., P.O 2118, Santa Cruz } \\
\text { CA } 95062 .\end{array}$ \\
\hline Huperzine-A & Huperzine Rx Brain ${ }^{R}$ & $50 \mathrm{MCG}$ & $\begin{array}{c}\text { National Organics Lab. INC. Nature } \\
\text { Plus, USA }\end{array}$ \\
\hline Bilobalide & $\begin{array}{l}\text { HAVASU NUTRITION } \\
\text { Neuro IGNITE }\end{array}$ & $\begin{array}{c}\text { Capsule } \\
\text { Ginkgo biloba extract } 50 \mathrm{mg} \\
\text { Huperzine A (Huperzia serrata } \\
\text { extract/leaf) } 10 \mathrm{mcg}\end{array}$ & $\begin{array}{l}\text { Havasu Nutrition, LLC19,046Bruce B, } \\
\text { Downs Blvd\#1090, Tampa, FL } 33647\end{array}$ \\
\hline Bilobalide & $\begin{array}{c}\text { Healthy Hey } \\
\text { Ginseng with Ginkgo Extract } \\
\text { Support memory and } \\
\text { concentration }\end{array}$ & $\begin{array}{l}160 \text { MG capsule } \\
\text { Ginkgo biloba } 60 \mathrm{mg}+ \\
\text { Ginseg panax } 100 \mathrm{mg}\end{array}$ & $\begin{array}{c}\text { Healthy Hey foods LLP. } \\
\text { 227, Building No-58, Mittal Ind, } \\
\text { Estate Andheri (E), Mumbai, } 400059 .\end{array}$ \\
\hline Bilobalide & $\begin{array}{l}\text { Vitamin } \\
\text { Ginkgo biloba (for } \\
\text { brain support) }\end{array}$ & 500 mg Capsule & $\begin{array}{c}\text { Plot No-57/1, Phase -1, G.I.D.C, vapi, } \\
\text { Gujrat-396 195, India }\end{array}$ \\
\hline Bilobalide & Ginkgo biloba & $\begin{array}{c}500 \mathrm{mg} \\
\text { Ginkgo biloba } 120 \mathrm{mg} \\
\text { Bacopa monnieri extract } 380 \mathrm{mg}\end{array}$ & $\begin{array}{l}\text { Herbal farm Lifecare Pvt. Ltd., C-86, } \\
\text { Pocket C, } 2^{\text {nd }} \text { Floor, Okhla Industrial } \\
\text { Area, Phase-I, New Delhi-110020. }\end{array}$ \\
\hline Bilobalide & $\begin{array}{l}\text { Natures velvet } \\
\text { Ginkgo Biloba }\end{array}$ & Capsule, $80 \mathrm{mg}$ & $\begin{array}{l}\text { Natures Velvet Lifecare, 103, Liberty } \\
\text { Plaza, himayat Nagar, Hyderabad, } \\
\text { Pin-500029, Telangana, India. }\end{array}$ \\
\hline Bilobalide & $\begin{array}{c}\text { Simply Nutra } \\
\text { Ginkgo Biloba with Brahmi }\end{array}$ & $\begin{array}{l}\text { Capsule, } 500 \mathrm{mg} \\
120 \mathrm{mg}+380 \mathrm{mg}\end{array}$ & $\begin{array}{c}\text { Soulager Healthcare Private Limited., } \\
\text { Scheme 53, Plot No-100, India, } \\
\text { M.P 452010. }\end{array}$ \\
\hline
\end{tabular}


Table 2. Cont.

\begin{tabular}{|c|c|c|c|}
\hline Phytoconstituents & Marketed Formulation & Dose and Form & Manufacturing Company \\
\hline Bilobalide & Ginkgo biloba & Capsule (60 mg) & $\begin{array}{l}\text { Sanathal Ring road, Opp GEB station, } \\
\text { Sanathal Ahmedabad, Gujarat. }\end{array}$ \\
\hline Bilobalide & $\begin{array}{l}\text { Nutriosys } \\
\text { Ginkgo biloba }\end{array}$ & Capsule (360 mg) & $\begin{array}{l}\text { Sanathal Ring road, Opp GEB station, } \\
\text { Sanathal Ahmedabad, Gujrat. }\end{array}$ \\
\hline Bilobalide & $\begin{array}{c}\text { iAYUR } \\
\text { Ginkgo Biloba }\end{array}$ & Capsule (500 m) & $\begin{array}{c}\text { Suimabhan Commerce Private } \\
\text { Limited A-1/224, Janakpuri, New } \\
\text { Delhi } 110058\end{array}$ \\
\hline Bilobalide & $\begin{array}{l}\text { Vita green } \\
\text { Ginkgo biloba }\end{array}$ & Capsule, $500 \mathrm{mg}$ & $\begin{array}{l}\text { Green cross, health Innovation, Plot } \\
\text { No-57/1, Phase 1, GIDC, Vapi-396195. }\end{array}$ \\
\hline Bilobalide & CoreFX Labs & $\begin{array}{c}\text { Capsule } \\
\text { Ginkgo biloba leaf ( } 24 \% \text { extract) } \\
50 \mathrm{mg} \text {, Bacopa monnieri leaf } \\
\text { extract ( } 20 \% \text { bacosides ) } \\
120 \mathrm{mg}, \\
\text { Huperzine A (aerial plant) } \\
10 \mathrm{mcg}\end{array}$ & $\begin{array}{l}\text { Xtreme Ai, } 100 \text { Orandorf, Dr\# 775, } \\
\text { Brighton MI } 48116 .\end{array}$ \\
\hline Bilobalide & $\begin{array}{l}\text { Body BRAIN SUPPORT } \\
\text { Dietary Supplements }\end{array}$ & $\begin{array}{c}\text { Capsule } \\
\text { Bacopa monnieri whole plant } \\
\text { extract } 200 \mathrm{mg} \text {, Ginkgo biloba } \\
\text { leaf extract } 100 \mathrm{mg}, \text { Huperzine } \\
\text { A ( Huperiza serrata leaf } \\
\text { standard extract) } 250 \mathrm{mcg} \\
\text { and others }\end{array}$ & $\begin{array}{c}1 \text { Body } 5940 \text { S. Rainbow Blvd, Las } \\
\text { Vegas, NV } 89118\end{array}$ \\
\hline Huperzine A & $\begin{array}{l}\text { FOCUS ELITE } \\
\text { Support Brain's Focus, } \\
\text { Memory and clarity }\end{array}$ & $\begin{array}{c}\text { Capsule } \\
\text { Huperzine A complex ( } \\
\text { Huperzia serrata } 25 \mathrm{mcg}), \\
\text { Ginkgo biloba leaf extract } \\
50 \mathrm{mg} \text {, Bacopa monneri extract } \\
\text { of whole herb } 75 \mathrm{mg} \\
\text { and others }\end{array}$ & $\begin{array}{c}\text { Elite source labs } \\
130 \text { Corridor Rd,\# 3259, Ponte Vedra, } \\
\text { FL 32004, USA }\end{array}$ \\
\hline Bilobalide & $\begin{array}{c}\text { NOW Brain Elevate } \\
\text { Cognitive functions } \\
\text { With Ginkgo Biloba, Rose OX } \\
\text { and Phosphatidyl Serine }\end{array}$ & $\begin{array}{c}\text { Capsule } \\
\text { Ginkgo Extract (Ginkgo biloba } \\
\text { leaf ) } 60 \mathrm{mg} \text {, } \\
\text { Huperzine complex } \\
\text { ( Huperzia serrata/Moss) } \\
25 \text { mcg } \\
\text { and others }\end{array}$ & $\begin{array}{l}\text { NOW FOODS, } 395 \text { S Glen Ellyn Rd, } \\
\text { Bloomingdale, IL 60108, USA }\end{array}$ \\
\hline Bilobalide & NEURA-SPARK & $\begin{array}{c}\text { Capsule, } \\
\text { Ginkgo biloba } 50 \mathrm{mg}, \\
\text { Huperzine A } 10 \mathrm{mcg}, \text { Bacopa } \\
\text { monnieri ( } 20 \% \text { bacosides, } \\
\text { herb) } 300 \mathrm{mcg} \text { and others }\end{array}$ & $\begin{array}{c}\text { NUTRACHAMPS Inc. AURORA, } \\
\text { ON, L4G1M2 }\end{array}$ \\
\hline Bilobalide & $\begin{array}{l}\text { Vitacern } \\
\text { BRAIN FUEL }\end{array}$ & $\begin{array}{c}\text { Capsule } \\
\text { Ginkgo Biloba leaf ( } 24 \% \\
\text { extract) } 50 \mathrm{mg} \text {, Bacopa monnieri } \\
\text { leaf extract } 120 \mathrm{mg} \text {, Huperzine } \\
\text { A ( aerial plant) } 10 \mathrm{mcg} \\
\text { and others }\end{array}$ & $\begin{array}{l}\text { Vitacerna, Suite \#7004, } 3422 \text { SW, } 15 \\
\text { street, Deerfield Beach, FL33,442USA }\end{array}$ \\
\hline Huperzine $-\mathrm{A}$ & $\begin{array}{l}\text { Double Woods } \\
\text { Supplements } \\
\text { HUPERZINE -A }\end{array}$ & $\begin{array}{c}\text { Tablet } \\
\text { Huperzine-A } 200 \mathrm{mcg}\end{array}$ & $\begin{array}{c}\text { Double Woods LLC, } 3510 \text { SCOOTS } \\
\text { LN STE 219, PHILADELPHIA, PA } \\
\text { 19129, United States }\end{array}$ \\
\hline
\end{tabular}


Table 2. Cont.

\begin{tabular}{|c|c|c|c|}
\hline Phytoconstituents & Marketed Formulation & Dose and Form & Manufacturing Company \\
\hline $\begin{array}{l}\text { Jatamansone } \\
\text { Celastrine }\end{array}$ & $\begin{array}{l}\text { Ayukriti HERBALS } \\
\text { Memokriti }{ }^{\mathrm{R}} \\
\text { capsule }^{\text {capula }}\end{array}$ & $\begin{array}{l}\text { Brahmi (Bacopa monnieri ) Pl } \\
\text { Ext. } 100 \mathrm{mg} \text {, Jatamansi } \\
\text { (Nardostachys jatamansi) Rt. } 60 \\
\text { mg. Jyotishmati (Celastrus } \\
\text { paniculatus) Rt. } 60 \mathrm{mg} \\
\text { and others. }\end{array}$ & $\begin{array}{l}\text { HARASHA PHARMA Private } \\
\text { Limited. PiyauManihariNarela road, } \\
\text { Kundli, Distt. Sonepat } \\
\text { (Haryana) } \\
\text { Harasha Pharma Pvt Ltd } 159 \text { A DG II } \\
\text { D BLOCK VIKASPURI NEW DELHI }\end{array}$ \\
\hline Jatamansone & $\begin{array}{l}\text { Indiveda Ayurvedic Herbs } \\
\text { Organic Jatamansi } \\
\text { Root Powder } \\
\text { (Nardostatchysjatamansi) }\end{array}$ & $\begin{array}{l}100 \text { g powder, Pure organic } \\
\text { Jatamansi Root Powder }\end{array}$ & $\begin{array}{l}\text { Ayuish Biotech \&lifescience } \\
\text { Company, Chanarthal road, } \\
\text { Kurukshetra, Haryana-136119 }\end{array}$ \\
\hline Jatamansone & $\begin{array}{l}\text { Ayurvedic Proprietary } \\
\text { Medicine } \\
\text { Nurayurich } \\
\text { Capsule }\end{array}$ & $\begin{array}{c}\text { Capsule } \\
\text { Nardostachys jatamansi } \\
75 \mathrm{mg} \text { each } \\
\text { Others } 67 \mathrm{mg}\end{array}$ & $\begin{array}{c}\text { Saived Pharma Private Limited, C } \\
\text { 4/35, MIDC, Jejuri, Tal-Purandar, } \\
\text { Distt-Pune-412303 }\end{array}$ \\
\hline Jatamansone & $\begin{array}{l}\text { VitaGreen } \\
\text { Jatamansi }\end{array}$ & $\begin{array}{c}\text { Capsule } \\
\text { Jatamansi Extract } \\
\text { (Nardostachys jatamansi) } \\
500 \mathrm{mg}\end{array}$ & $\begin{array}{c}\text { Manufacturing LicenceNo GA/1736, } \\
\text { Green Cross Health Innovation, Plot } \\
\text { No- 57/1, Phase 1, G.I.D.C, Vapi- } \\
396195 .\end{array}$ \\
\hline Jatamansone & $\begin{array}{c}\text { HealthVit } \\
\text { Jatamansi Powder } \\
\text { Nardostachys jatamansi }\end{array}$ & $\begin{array}{c}100 \mathrm{~g} \\
\text { Jatamansi root powder } \\
\text { (Nardostachy s jatamansi) } 100 \% \\
w / w\end{array}$ & $\begin{array}{l}\text { West-Coast Pharmaceutical Works } \\
\text { Ltd., Ahmedabad - } 382 \text { 481, Gujrat. }\end{array}$ \\
\hline Jatamansone & $\begin{array}{l}\text { Himalaya } \\
\text { Herbal Health care } \\
\text { Mentat DS }\end{array}$ & $\begin{array}{c}100 \mathrm{~mL} \text { Syurp } \\
\text { Bacopa monnieri } 288 \mathrm{mg}, \\
\text { Jatamansi } 104 \mathrm{mg}, \text { Celastrus } \\
\text { paniculatus } 64 \mathrm{mg}\end{array}$ & $\begin{array}{c}\text { Himalaya Drug company, Makali, } \\
\text { Bengaluru }\end{array}$ \\
\hline Jatamansone & $\begin{array}{c}\text { Herbal Hills } \\
\text { Jatamansi Powder } \\
\text { Nardostachys jatamansi }\end{array}$ & $\begin{array}{l}100 \mathrm{~g} \text { powder } \\
\text { Jatamansi Powder }\end{array}$ & $\begin{array}{l}\text { Isha Agro Developers PVT.LTD. } \\
\text { Unit No- } 36 \text { A/55AB, LonavalaCo.op. } \\
\text { Indl. Est. Ltd, Village- Nangargaon, } \\
\text { Lonavala, Taluka-Maval, Distt } \\
\text { Pune-410401, Maharashtra, India. }\end{array}$ \\
\hline Jatamansone & $\begin{array}{c}\text { Amalath } \\
\text { Jatamansi Extract }\end{array}$ & $\begin{array}{l}\text { Jatamansi root extract, 5:1 } \\
\text { (Capsule } 500 \mathrm{mg})\end{array}$ & $\begin{array}{l}\text { Devki Pharmacy, Kakheri, Kaithal } \\
\text {-136033, Haryana, India. }\end{array}$ \\
\hline Jatamansone & $\begin{array}{c}\text { Kerala aurveda }^{\mathrm{TM}} \\
\text { GANDHA THAILAM }\end{array}$ & $\begin{array}{c}\text { GANDHA THAILAM } \\
\text { Capsule } 300 \mathrm{mg} \\
\text { Jatamansi (Nardostachys } \\
\text { jatamansi) } 0.5 \mathrm{mg} \text { and others }\end{array}$ & $\begin{array}{c}\text { Kerala Ayurveda, Ltd, Athani 683585, } \\
\text { Aluva, Kerala, India. }\end{array}$ \\
\hline Bilobalide & $\begin{array}{c}\text { Standardized Ginkgo Biloba } \\
\text { Extract as } \\
\text { Herbal Supplement }\end{array}$ & $\begin{array}{c}\text { Capsule } \\
\text { Ginkgo Biloba Extract (leaf) } \\
60 \mathrm{mg} \\
(50: 1)\end{array}$ & $\begin{array}{l}\text { 21st Century Healthcare, Inc. } \\
\text { 2119 S. Wilson St. Tempe, AZ } \\
\text { 85282, USA. }\end{array}$ \\
\hline Bilobalide & $\begin{array}{l}\text { MRM GINKGO B } \\
\text { Supports circulation and } \\
\text { mental functions Dietary } \\
\text { Supplements }\end{array}$ & $\begin{array}{c}\text { Capsule } \\
\text { Ginkgo Biloba Extract (60 mg) }\end{array}$ & $\begin{array}{l}\text { MRM } 2665 \text { Vista Pacific Dr. } \\
\text { Oceanside CA 92056, USA }\end{array}$ \\
\hline Bilobalide & Ginkgo+Bilbery+Lutein & Ginkgo Biloba 60 mg (capsule) & $\begin{array}{l}\text { Biotrex Nutraceutical, Sanathal ring } \\
\text { Road, Opp GEB Station, Sanathal, } \\
\text { Ahmedabad, Gujrat. }\end{array}$ \\
\hline
\end{tabular}

\section{Final Remarks and Future Prospects}

Sesquiterpene is an important category of terpenoids, found to possess a large spectrum of biological activities. As discussed in the present review, these plant actives have 
been reported to play a significant role in the improvement of cholinergic transmission by inhibiting the AChE. In literature, multiple sesquiterpenes havebeen evident from the past decade to possess the AChE inhibitory activity. The percentage of compounds having anti acetylcholinesterase potential from different categories of sesquiterpenes has been indicated in Figure 5.

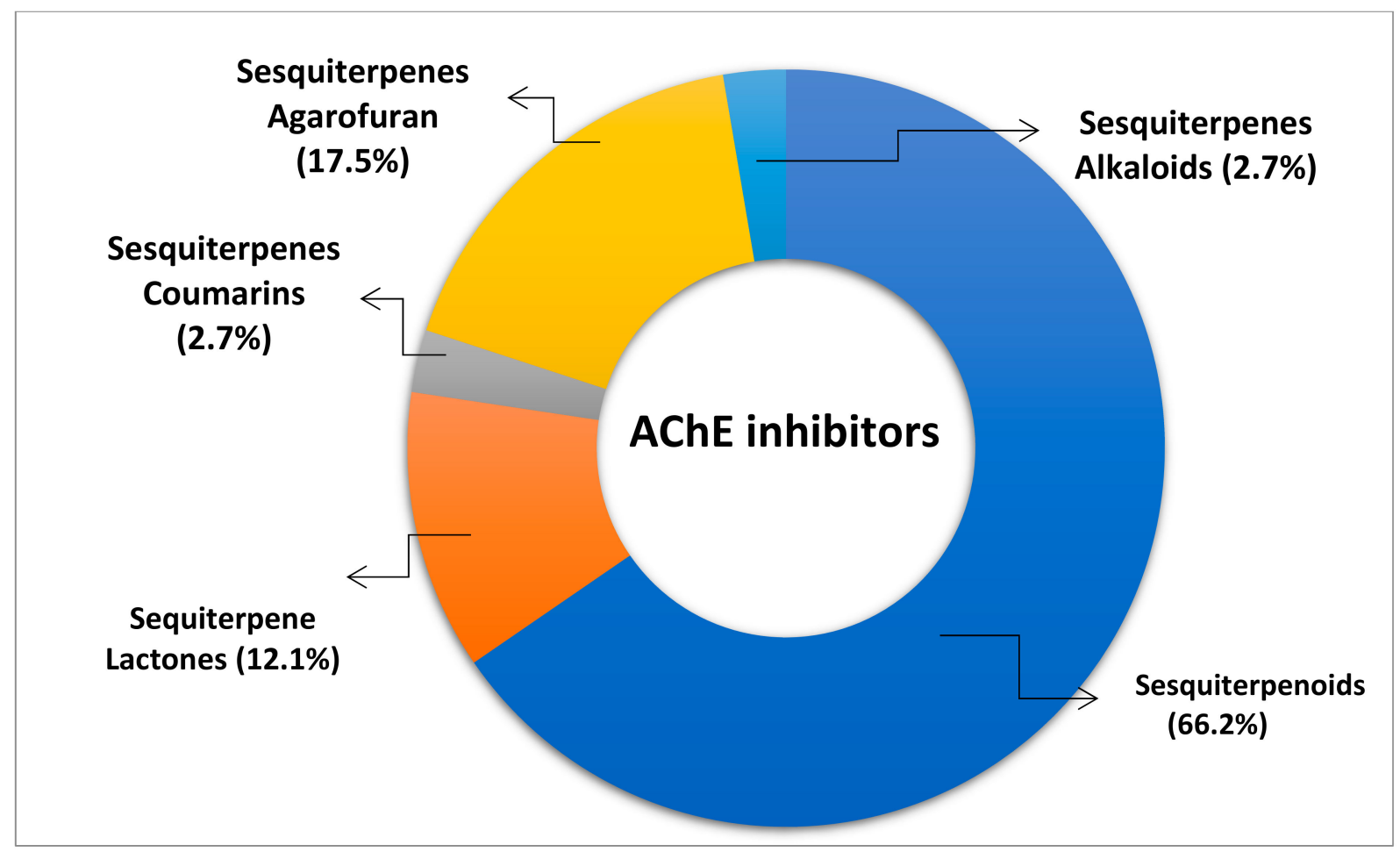

Figure 5. Percentage of various categories of sesquiterpenes with AChE inhibitory potential.

Critically analyzing the literature, it has been found that 12 compounds out of total 58 sesquiterpenes were reported to possess $\mathrm{IC}_{50}<9 \mu \mathrm{M}$ and can be considered as potential candidates for the improvement of learning and memory. However, mere possession of significant $\mathrm{IC}_{50}$ (for $\mathrm{AChE}$ ) should not be the criteria for the selection of a compound for anti-Alzheimer potential. Because the evaluation of cholinesterase inhibition potential of compounds, with carbonyl group, by in vitro methods such as Ellman reagent could produce the false positive [149]. Hence, they should be further evaluated in animal models for final confirmation of results.

In the light of reviewed articles, it can also be stated that the Asteraceae/Compositae family plants reported yielding the sesquiterpenes lactones such as amberboin and lipidiol that were having very low inhibitory concentration $\left(\mathrm{IC}_{50}=0.8 \mu \mathrm{M}\right.$ and $0.5 \mu \mathrm{M}$, respectively) against acetylcholinesterase. Hence, the herbs from this family could be further explored for plant actives with significant anti-Alzheimer potential.

Furthermore, the pathophysiology of Alzheimer's disease includes the degeneration of neurons at vulnerable spots in the brain such as thehippocampus and cortex region [150-152]. Hence, to be a potential candidate for Alzheimer's therapy, a compound must pass the blood-brain barrier (BBB) and should be sufficiently bioavailable in the affected area of the brain. The lipophilic nature and low polarity of sesquiterpenes render them bioavailable at specific sites [105,153]. Moreover, the various tools (such as Molinspiration, Swiss ADME) from the molecular modeling docking portal can be employed to predict the probability of a novel compound for crossing the BBB. The ability of the ambrosin, a sesquiterpene, was successfully predicted by using this technique [144]. Moreover, the non-polar solvents can be used for better extraction of lipophilic sesquiterpenes from the herbs. 
Recent clinical studies have shown that the AChE inhibitors significantly alleviate Alzheimer's symptoms and also lessen the rates of related mortality [154]. However, most of the time the patients discontinue their use due to associated side effects. Hence, it is very important to assess the toxicological profile of the novel compounds. Unfortunately, most of the plant actives reported in this article were not evaluated for the unwanted side effects. Furthermore, the Galliardin, a guainolide-type sesquiterpene, possesses good AChE inhibitory potential, but it also has significant cytotoxic properties [123]. Therefore, it is suggested that the derivatization of potential compounds could be carried out in the future to obtain clinically effective AChE inhibitors with less or no cytotoxicity. Moreover, the promising sesquiterpenes should also be assessed for clinical data to obtainreliable and safe anti-Alzheimer candidates.

Furthermore, it has been established that for the proper functioning of neurons, there should be a critical balance between the excitatory and inhibitory neurotransmitters [155-158]. It is evident that $\beta$-amyloid (A $\beta$ ) could also enhance the translation of GABA $_{A}$ receptor (at $\alpha_{6}$ subunit) by the phosphorylation of mTOR and ERK in the cerebellum of experimental mice $[28,159,160]$, and hence an increase in inhibitory transmission at synapse affects the learning and memory process [161]. Sesquiterpenes such asBilabolide could help in achieving the equilibrium of excitatory and inhibitory transmission because it was reported as an antagonist to $\alpha_{1} \beta_{2} \gamma_{21}$ subunits of $\mathrm{GABA}_{\mathrm{A}}$ receptors that enhanced the excitability of neurons in hippocampal slices [139]. Moreover, the A $\beta$ application also increases the concentration of AChE in cultures and the simultaneous feeding of experimental animals with farnesene (a sesquiterpene) significantly reduces the enzyme concentration [162]. Hence, it could be interesting to explore the effect of potential AChE inhibitors in $\beta$-amyloid deposition and in GABAergic neuronal transmission.

In recent years, the treatment paradigm for $\mathrm{AD}$ is moving toward alleviating the inflammation associated with the development of this disease [163,164]. Hence, the exploration of novel sesquiterpenes for the expression of NF-K $\beta$ p 65 could be a target for scientists for the management of neurodegenerative disorderssuch asAD.

Thus, this review paper comprehensively discussed the various types of sesquiterpenes, active constituents related, and their devoted involvement toward the improvement of cholinergic transmission by inhibiting the AChE. Their involvement in different alternate targets for AD management was also discussed briefly. The described sesquiterpenes are supposed to act as novel compounds for the researchers willing to find some other alternatives than the existing ones for the possible treatment of neurodegenerative diseases, i.e., Alzheimer's disease.

\section{Conclusions}

No doubt extensive researchhas been carried out to explore suitable candidates for $\mathrm{AD}$ management. In spite of the availability of bulk knowledge related to this progressive disorder, we have access only to symptomatic treatment, not to a complete cure. Improvement in cholinergic transmission by inhibiting the AChE was considered to delay the $\mathrm{AD}$ progression and relieve the $\mathrm{AD}$-associated symptoms. This review mainly focuses on the various sesquiterpenes acting as potential acetylcholinesterase inhibitors and also summarizes their role on alternate AD targets. The literature revealed the potential of sesquiterpenes such as amberboin and lipidiol in the inhibition of AChE. Moreover, the sesquiterpenes such as Farnesene, Bilabolide, and Jatamansone were found to exert a significant effect on different $\mathrm{AD}$ targets such as $\mathrm{A} \beta$ plaque, neuron excitability, and oxidative stress. Nowadays, the paradigm for AD management has shifted toward the management of neuroinflammation by novel compounds. Sesquiterpenes such asambrosin and nootkatone alleviate neuroinflammation by reducing the expression of transcription factor NF- $k \beta$ p65.

In future studies, a scientific approach can be acquired from this systematized information to prepare a baseline for the further consideration of natural cognitive enhancers (especially sesquiterpenes) in age-related diseases such asAD. Moreover, the described 
moieties could be further investigated for better derivatives in terms of safety and efficacy. Furthermore, it is also speculated that a mere delay in the symptoms of AD by one year could reduce the patient load significantly (upto 9.2 million) in 2050. Hence, it can also be concluded that the use of suggested herbs as nutraceuticals/dietary supplements could significantly alleviate the symptoms of $\mathrm{AD}$ and prove highly beneficial for mankind.

Author Contributions: Data curation, Writing original draft preparation, A.A.; Data curation, Writing original draft preparation, R.C.; Writing, reviewing and Editing, R.R.; Writing, reviewing and editing, M.H.R.; Reviewing, editing and validation, D.K.; Writing, reviewing and editing, M.F.A.; Writing, reviewing and editing, A.S.; Conceptualization, editing and validation, S.M.A.K.; Reviewing, editing, visualization, H.R.E.-S.; Writing, reviewing, editing and validation, M.K.; Reviewing, Editing and Validation, G.M.A.; Conceptualization, reviewing: M.M.A.-D.; Conceptualization, supervision, writing-review and revision, V.M. All authors have read and agreed to the published version of the manuscript.

Funding: This research work was funded by the Deanship of Scientific Research at Princess Nourah bint Abdulrahman University, through the Fast-track Research Funding Program.

Institutional Review Board Statement: Not applicable.

Informed Consent Statement: Not applicable.

Conflicts of Interest: The authors declare no conflict of interest.

$\begin{array}{ll}\text { Abbreviations } \\ \text { AChE } & \text { Acetylcholinesterase } \\ \text { AD } & \text { Alzheimer's disease } \\ \text { APP } & \text { amyloid precursor protein } \\ \text { ARD } & \text { Aromadendrane-4 } \beta, 10 \alpha \text {-diol } \\ \text { A } \beta & \text { Amyloid Beta } \\ \text { BACE1 } & \text { B-site APP Cleaving Enzyme1 } \\ \text { BChE } & \text { Butylcholinesterase } \\ \text { BuTChERK } & \text { ButyrylthiocholineExtracellular signal regulated kinase } \\ \text { FPP } & \text { Farnesyl Pyrophosphate } \\ \text { HDS } & \text { 13-hydroxy-8,9-dehydroshizukanolide } \\ \text { ICO } & \text { Isocubebenol } \\ \text { LAMI } & \text { Learning and Memory impairment } \\ \text { LPS } & \text { Lipopolysaccharide } \\ \text { MDA } & \text { Malondialdehyde level } \\ \text { mTOR } & \text { Mammalian target of rapamycin } \\ \text { MWM } & \text { Morris Water Maze } \\ \text { NF-KB } & \text { Nuclear factor kappa-light-chain-enhancer of activated B cells } \\ \text { NLRP3 } & \text { Nucleotide-binding domain and leucine-rich repeat protein } 3 \\ \text { NMDA } & \text { N-methyl-D-aspartate } \\ \text { PDA } & \text { Podoandin } \\ \text { PS-1 } & \text { Presenilin-1 } \\ \text { SC } & \text { Sesquiterpenecoumarins } \\ \text { SLs } & \text { Sesquiterpene Lactones } \\ \end{array}$

\section{References}

1. Essa, M.M.; Vijayan, R.K.; Castellano-Gonzalez, G.; Memon, M.A.; Braidy, N.; Guillemin, G.J. Neuroprotective Effect of Natural Products Against Alzheimer's Disease. Neurochem. Res. 2012, 37, 1829-1842. [CrossRef] [PubMed]

2. Korczyn, A.D.; Vakhapova, V. The prevention of the dementia epidemic. J. Neurol. Sci. 2007, 257, 2-4. [CrossRef] [PubMed]

3. Huang, L.; Su, T.; Li, X. Natural products as sources of new lead compounds for the treatment of Alzheimer's disease. Curr. Top. Med. Chem. 2013, 13, 1864-1878. [CrossRef] [PubMed]

4. Johnson, G.; Moore, S.W. The peripheral anionic site of acetylcholinesterase: Structure, functions and potential role in rational drug design. Curr. Pharm. Des. 2006, 12, 217-225. [CrossRef] [PubMed] 
5. Camps, P.; El-Achab, R.; Morral, J.; Torrero, D.M.; Badia, A.; Banos, J.E.; Vivas, N.M.; Barril, X.; Orozco, M.; Luque, F.J. New tacrine-huperzine A hybrids (huprines): Highly potent tight-binding acetylcholinesterase inhibitors of interest for the treatment of Alzheimer's disease. J. Med. Chem. 2000, 43, 4657-4666. [CrossRef]

6. Li, Y.; Zhang, X.X.; Jiang, L.J.; Yuan, L.; Cao, T.T.; Li, X.; Dong, L.; Li, Y.; Yin, S.F. Inhibition of acetylcholinesterase (AChE): A potential therapeutic target to treat Alzheimer's disease. Chem. Biol. Drug. Des. 2015, 86, 776-782. [CrossRef] [PubMed]

7. Kumar, G.P.; Khanum, F. Neuroprotective potential of phytochemicals. Pharmacogn. Rev. 2012, 6, 81-90. [CrossRef]

8. Rahman, M.H.; Akter, R.; Bhattacharya, T.; Abdel-Daim, M.M.; Alkahtani, S.; Arafah, M.W.; Al-Johani, N.S.; Alhoshani, N.M.; Alkeraishan, N.; Alhenaky, A.; et al. Resveratrol and neuroprotection: Impact and its therapeutic potential in Alzheimer's disease. Front. Pharmacol. 2020, 11. [CrossRef] [PubMed]

9. Kelley, B.J.; Petersen, R.C. Alzheimer's disease and mild cognitive impairment. Neurol. Clin. 2007, 25, 577-609. [CrossRef]

10. Chauhan, V.; Chauhan, A. Oxidative stress in Alzheimer's disease. Pathophysiology 2006, 13, 195-208. [CrossRef] [PubMed]

11. Maltsev, A.V.; Bystryak, S.; Galzitskaya, O.V. The role of $\beta$-amyloid peptide in neurodegenerative diseases. Ageing Res. Rev. 2011, 10, 440-452. [CrossRef]

12. Anand, A.; Patience, A.A.; Sharma, N.; Khurana, N. The present and future of pharmacotherapy of Alzheimer's disease: A comprehensive review. Eur. J. Pharmacol. 2017, 815, 364-375. [CrossRef] [PubMed]

13. Madeo, J.; Elsayad, C. The role of oxidative stress in Alzheimer's disease. J. Alzheimers Dis. 2013, 3, 116-121. [CrossRef]

14. Godyn, J.; Jonczyk, J.; Panek, D.; Malawska, B. Therapeutic strategies for Alzheimer's disease in clinical trials. Pharmacol. Rep. 2016, 68, 127-138. [CrossRef]

15. Henstridge, C.M.; Pickett, E.; Spires-Jones, T.L. Synaptic pathology: A shared mechanism in neurological disease. Ageing Res. Rev. 2016, 28, 72-84. [CrossRef] [PubMed]

16. Bartus, R.T. On neurodegenerative diseases, models, and treatment strategies: Lessons learned and lessons forgotten a generation following the cholinergic hypothesis. Exp. Neurol. 2000, 163, 495-529. [CrossRef]

17. Bartus, R.T.; Dean, R.L.; Beer, B.; Lippa, A.S. The cholinergic hypothesis of geriatric memory dysfunction. Science 1982, 217, 408-414. [CrossRef] [PubMed]

18. Hasselmo, M.E. The role of acetylcholine in learning and memory. Curr. Opin. Neurobiol. 2006, 16, 710-715. [CrossRef]

19. Rees, T.M.; Brimijoin, S. The role of acetylcholine in the pathogenesis of Alzheimer's disease. Drugs Today 2003, 39, 75-83. [CrossRef]

20. Quinn, D.M. Acetylcholinesterase: Enzyme structure, reaction dynamics, and virtual transition states. Chem. Rev. 1987, 87, 955-979. [CrossRef]

21. Wang, Q.; Wang, C.; Zuo, Y.; Wang, Z.; Yang, B.; Kuang, H. Compounds from the roots and rhizomes of Valerianaamurensis protect against neurotoxicity in PC12 cells. Molecules 2012, 17, 15013-15021. [CrossRef]

22. Massoulie, J.; Pezzementi, L.; Bon, S.; Krejci, E.; Vallette, F.M. Molecular and cellular biology of cholinesterases. Prog. Neurobiol. 1993, 41, 31-91. [CrossRef]

23. Reid, G.A.; Chilukuri, N.; Darvesh, S. Butyrylcholinesterase and the cholinergic system. Neuroscience 2013, 234, 53-68. [CrossRef] [PubMed]

24. Masson, P.; Lockridge, O. Butyrylcholinesterase for protection from organophosphorus poisons: Catalytic complexities and hysteretic behavior. Arch. Biochem. Biophys. 2010, 494, 107-120. [CrossRef] [PubMed]

25. Mesulam, M.; Guillozet, A.; Shaw, P.; Quinn, B. Widely spread butyrylcholinesterase can hydrolyze acetylcholine in the normal and Alzheimer brain. Neurobiol. Dis. 2002, 9, 88-93. [CrossRef] [PubMed]

26. Francis, P.T. The interplay of neurotransmitters in Alzheimer's disease. CNS Spectr. 2005, 10, 6-9. [CrossRef]

27. Dvir, H.; Silman, I.; Harel, M.; Rosenberry, T.L.; Sussman, J.L. Acetylcholinesterase: From 3D structure to function. Chem. Biol. Interact. 2010, 187, 10-22. [CrossRef]

28. Li, Y.; Sun, H.; Chen, Z.; Xu, H.; Bu, G.; Zheng, H. Implications of GABAergic neurotransmission in Alzheimer's disease. Front. Aging Neurosci. 2016, 8, 31. [CrossRef]

29. Del Monte-Millán, M.; García-Palomero, E.; Valenzuela, R.; Usán, P.; de Austria, C.; Muñoz-Ruiz, P.; Rubio, L.; Dorronsoro, I.; Martínez, A.; Medina, M. Dual binding site acetylcholinesterase inhibitors: Potential new disease-modifying agents for AD. J Mol. Neurosci. 2006, 30, 85-88. [CrossRef]

30. Castro, A.; Martinez, A. Targeting beta-amyloid pathogenesis through acetylcholinesterase inhibitors. Curr. Pharm. Des. 2006, 12, 4377-4387. [CrossRef]

31. Heinrich, M. Galanthamine from galanthus and other amaryllidaceae-Chemistry and biology based on traditional use. Alkaloids Chem. Biol. 2010, 68, 157-165. [CrossRef]

32. Thomsen, T.; Kewitz, H. Selective inhibition of human acetylcholinesterase by galanthamine in vitro and in vivo. Life Sci. 1990, 46, 1553-1558. [CrossRef]

33. Grossberg, G.T. Cholinesterase inhibitors for the treatment of Alzheimer's disease: Getting on and staying on. Curr. Ther. Res. 2003, 64, 216-235. [CrossRef]

34. Arendt, T.; Brückner, M.K.; Lange, M.; Bigl, V. Changes in acetylcholinesterase and butyrylcholinesterase in Alzheimer's disease resemble embryonic development-A study of molecular forms. Neurochem. Int. 1992, 21, 381-396. [CrossRef]

35. Schmidt, T.J. Structure-activity relationships of sesquiterpene lactones. Stud. Nat. Prod. Chem. 2006, 33, 309-392. [CrossRef] 
36. Melanie-Jayne, R.H.; Houghton, P.J. Plants used in Chinese and Indian traditional medicine for improvement of memory and cognitive function. Pharmacol. Biochem. Behav. 2003, 75, 513-527. [CrossRef]

37. Oh, M.S.; Huh, Y.; Bae, H.; Ahn, D.K.; Park, S.K. The multi-herbal formula Guibitang enhances memory and increases cell proliferation in the rat hippocampus. Neurosci. Lett. 2005, 379, 205-208. [CrossRef]

38. Das, A.; Shanker, G.; Nath, C.; Pal, R.; Singh, S.; Singh, H. A comparative study in rodents of standardized extracts of Bacopa monniera and Ginkgo biloba: Anticholinesterase and cognitive enhancing activities. Pharmacol. Biochem. Behav. 2002, 73, 893-900. [CrossRef]

39. Howes, M.J.; Houghton, P.J. Ethnobotanical treatment strategies against Alzheimer's disease. Curr. Alzheimer Res. 2012, 9, 67-85. [CrossRef]

40. Bond, M.; Rogers, G.; Peters, J.; Anderson, R.; Hoyle, M.; Miners, A.; Moxham, T.; Davis, S.; Thokala, P.; Wailoo, A.; et al. The effectiveness and cost-effectiveness of donepezil, galantamine, rivastigmine and memantine for the treatment of Alzheimer's disease (review of Technology Appraisal No. 111): A systematic review and economic model. Health Technol. Assess. 2012, 16, 1-470. [CrossRef]

41. Mancuso, C.; Siciliano, R.; Barone, E.; Preziosi, P. Natural substances and Alzheimer's disease: From preclinical studies to evidence based medicine. Biochimica Biophysica Acta (BBA) Mol. Basis Dis. 2012, 1822, 616-624. [CrossRef]

42. Chopra, K.; Misra, S.; Kuhad, A. Current perspectives on pharmacotherapy of Alzheimer's. Expert. Opin. Pharmacother. 2011, 12, 335-350. [CrossRef] [PubMed]

43. Rao, R.V.; Descamps, O.; John, V.; Bredesen, D.E. Ayurvedic medicinal plants for Alzheimer's disease: A review. Alzheimer's Res. Ther. 2012, 4, 22. [CrossRef] [PubMed]

44. Gliszczynska, A.; Brodelius, P.E. Sesquiterpene coumarins. Phytochem. Rev. 2012, 11, 77-96. [CrossRef]

45. Chunmei, Z.; Jianbo, J.; Mei, J.; Peihong, F. Acetylcholinesterase inhibitors and compounds promoting SIRT1 expression from Curcuma xanthorrhiza. Phytochem. Lett. 2015, 12, 215-219. [CrossRef]

46. Howes, M.J.R.; Perry, E. The role of phytochemicals in the treatment and prevention of dementia. Drugs Aging 2011, 28, 439-468. [CrossRef]

47. Owokotomo, I.A.; Ekundayob, O.; Abayomic, T.G.; Chukwuka, A.V. In-vitro anti-cholinesterase activity of essential oil from fourtropical medicinal plants. Toxicol. Rep. 2015, 2, 850-857. [CrossRef]

48. Shal, B.; Ding, W.; Ali, H.; Kim, Y.S.; Khan, S. Anti-neuroinflammatory potential of natural products in attenuation of Alzheimer's disease. Front. Pharmacol. 2018, 9. [CrossRef] [PubMed]

49. Cao, C.M.; Peng, Y.; Shi, Q.W.; Xiao, P.G. Chemical constituents and bioactivities of plants of chloranthaceae. Chem. Biodivers. 2008, 5, 219-238. [CrossRef] [PubMed]

50. Hu, X.R.; Wu, H.F.; Zhang, X.P.; Yang, J.S.; Dai, Z.; Lin, R.C.; Xu, X.D. A new sesquiterpene lactone from Sarcandra glabra. Nat. Prod. Res. 2013, 27, 1197-1201. [CrossRef]

51. Duan, H.Q.; Takaishi, Y.; Momota, H.; Ohmoto, Y.; Taki, T.; Jia, Y.F.; Li, D. Immunosuppressive sesquiterpene alkaloids from Tripterygium wilfordii. J. Nat. Prod. 2001, 64, 582-587. [CrossRef]

52. Melikov, E.M.; Serkerov, S.V.; Movsumov, G.D.; Mir-Babaev, N.F. Antiamnesic properties of the sesquiterpene lactone Azerin. Bull. Exp. Biol. Med. 1993, 115, 163-165. [CrossRef]

53. Merfort, I. Perspectives on sesquiterpene lactones in inflammation and cancer. Curr. Drug Targets 2011, 12, 1560-1573. [CrossRef]

54. Foglio, M.A.; Dias, P.C.; Antônio, M.A.; Possenti, A.; Rodrigues, R.A.; Da Silva, E.F.; Rehder, V.L.; De Carvalho, J.E. Antiulcerogênic activity of some sesquiterpene lactones isolated from Artemisia annua L. Planta Medica 2002, 6, 515-518. [CrossRef]

55. Ordonez, P.E.; Quave, C.L.; Reynolds, W.F.; Varughese, K.I.; Berry, B.; Breen, P.J.; Malagon, O.; Smeltzer, M.S.; Compadre, C.M. Sesquiterpene lactones from Gynoxysverrucosa and their anti-MRSA activity. J. Ethnopharmacol. 2011, 137, 1055-1059. [CrossRef] [PubMed]

56. Wang, L.J.; Xiong, J.; Liu, S.T.; Liu, X.H.; Hu, J.F. Sesquiterpenoids from Chloranthushenryi and their anti-neuroinflammatory activities. Chem. Biodivers. 2014, 11, 919-928. [CrossRef]

57. Chougouo, R.D.K.; Nguekeu, Y.M.M.; Dzoyem, J.P.; Maurice, D.; Awouafack, J.K.; Pierre, T.; Lyndy, J.M.; Jacobus, N.E. Antiinflammatory and acetylcholinesterase activity of extract, fractions and five compounds isolated from the leaves and twigs of Artemisia annua growing in Cameroon. Springer Plus 2016, 5, 1525. [CrossRef] [PubMed]

58. Fraga, B.M. Natural sesquiterpenoids. Nat. Prod. Rep. 2008, 25, 1180-1209. [CrossRef]

59. Bennett, M.H.; Mansfield, J.W.; Lewis, M.J.; Beale, M.H. Cloning and expression of sesquiterpene synthase genes from Lettuce (Lactuca sativa L.). Phytochemistry 2002, 60, 255-261. [CrossRef]

60. Cheng, A.X.; Xiang, C.Y.; Li, J.X.; Yang, C.Q.; Hu, W.L.; Wang, L.J.; Lou, Y.; Chen, X.Y. The rice (E)- $\beta$-caryophyllene synthase (OsTPS3) accounts for the major inducible volatile sesquiterpenes. Phytochemistry 2007, 68, 1632-1641. [CrossRef] [PubMed]

61. Hang, Z.; Gao, Z.H.; Wei, J.H.; Xu, Y.H.; Li, Y.; Yang, Y.; Meng, H.; Sui, C.; Wang, M.X. The mechanical wound transcriptome of three-year-old Aquilaria sinensis. Acta Pharm. Sin. 2012, 47, 1106-1110.

62. Chan, W.K.; Tan, L.T.H.; Chan, K.G.; Lee, L.H.; Goh, B.H. Nerolidol: A sesquiterpene alcohol with multi-faceted pharmacological and biological activities. Molecules 2016, 21, 529. [CrossRef] [PubMed]

63. Elmann, A.; Telerman, A.; Ofir, R.; Kashman, Y.; Lazarov, O. $\beta$-amyloid cytotoxicity is prevented by natural achillolide A. J. Nat. Med. 2018, 72, 626-631. [CrossRef] 
64. De Cássia Da Silveira e Sá, R.; Andrade, L.N.; De Sousa, D.P. Sesquiterpenes from essential oils and anti-inflammatory activity. Nat. Prod. Commun. 2015, 10, 1767-1774. [CrossRef]

65. Picaud, S.; Olsson, M.E.; Brodelius, P.E. Improved conditions for production of recombinant plant sesquiterpene synthases in Escherichia coli. Prot. Expr. Purif. 2007, 51, 71-79. [CrossRef] [PubMed]

66. Little, D.B.; Croteau, R.B. Alteration of product formation by directed mutagenesis and truncation of the multiple-product sesquiterpene synthases $\delta$-selinene synthase and $\gamma$-humulene synthase. Arch. Biochem. Biophys. 2002, 402, 120-135. [CrossRef]

67. Schnee, C.; Kollner, T.G.; Gershenzon, J.; Degenhardt, J. The maize gene terpene synthase 1 encodes a sesquiterpene synthase catalyzing the formation of (E)- $\beta$-farnesene, (E)-nerolidol, and (E,E)-farnesol after herbivore damage. Plant. Physiol. 2002, 130, 2049-2060. [CrossRef] [PubMed]

68. Ivanescu, B.; Miron, A.; Corciova, A. Sesquiterpene lactones from Artemisia genus: Biological activities and methods of analysis. J. Anal. Methods. Chem. 2015, 21. [CrossRef]

69. Chaturvedi, D. Sesquiterpene lactones: Structural diversity and their biological activities. In Opportunity, Challenge and Scope of Natural Products in Medicinal Chemistry; Research Signpost: Trivandrum, Kerala, India, 2011; pp. 313-334.

70. Chadwick, M.; Trewin, H.; Gawthrop, F.; Wagstaff, C. Sesquiterpenoids lactones: Benefits to plants and people. Int. J. Mol. Sci. 2013, 14, 12780-12805. [CrossRef] [PubMed]

71. Houghton, P.J.; Ren, Y.; Howes, M.J. Acetylcholinesterase inhibitors from plants and fungi. Nat. Prod. Rep. 2006, 23, 181-199. [CrossRef]

72. Williams, P.; Sorribas, A.; Howes, M.J. Natural products as a source of Alzheimer's drugs leads. Nat. Prod. Rep. 2011, 28, 48-77. [CrossRef] [PubMed]

73. Mukherjee, P.K.; Kumar, V.; Mal, M.; Houghton, P.J. Acetylcholinesterase inhibitors from plants. Phytomedicine 2007, 14, 289-300. [CrossRef]

74. Orhan, G.; Orhan, I.; Subutay-Oztekin, N.; Ak, F.; Sener, B. Contemporary anticholinesterase pharmaceuticals of natural origin and their synthetic analogues for the treatment of Alzheimer's disease. Recent. Pat. CNS Drug. Discov. 2009, 4, 43-51. [CrossRef]

75. Cos, P.; Vlietinck, A.J.; Vanden Berghe, D.; Maes, L. Anti-infective potential of natural products: How to develop a stronger in vitro 'proof-of-concept'. J. Ethnopharmacol. 2006, 106, 290-302. [CrossRef] [PubMed]

76. Ellman, G.L.; Courtney, K.D.; Andres, V.; Featherstone, R.M. A new and rapid colorimetric determination of acetylcholinesterase activity. Biochem. Pharmacol. 1961, 7, 88-95. [CrossRef]

77. Lopez, S.; Bastida, J.; Viladomat, F.; Codina, C. Acetylcholinesterase inhibitory activity of some Amaryllidaceae alkaloids and Narcissus extracts. Life Sci. 2002, 71, 2521-2529. [CrossRef]

78. Rhee, I.K.; van de Meent, M.; Ingkaninan, K.; Verpoorte, R. Screening for acetylcholinesterase inhibitors from Amaryllidaceae using silica gel thin-layer chromatography in combinatioin with bioactivity staining. J. Chromatogr. A 2001, 915, 217-223. [CrossRef]

79. Marston, A.; Kissling, J.; Hostettmann, K. A rapid TLC bioautographic method for the detection of acetylcholinesterase and butyrylcholinesterase inhibitors in plants. Phytochem. Anal. 2002, 13, 51-54. [CrossRef]

80. Di Giovanni, S.; Borloz, A.; Urbain, A.; Marston, A.; Hostettmann, K.; Carrupt, P.A.; Reist, M. In vitro screening assays to identify natural or synthetic acetylcholinesterase inhibitors: Thin layer chromatography versus microplate methods. Eur. J. Pharm. Sci. 2008, 33, 109-119. [CrossRef]

81. Yang, J.L.; Dao, T.T.; Hien, T.T.; Zhao, Y.M.; Shi, Y.P. Further sesquiterpenoids from the rhizomes of Homalomena occulta and their anti-inflammatory activity. Bioorg. Med. Chem. Lett. 2019, 29, 1162-1167. [CrossRef] [PubMed]

82. Xu, J.; Ji, F.; Cao, X.; Ma, J.; Ohizumi, Y.; Lee, D.; Guo, Y. Sesquiterpenoids from an edible plant Petasites japonicus and their promoting effects on neurite outgrowth. J. Funct. Foods 2016, 22, 291-299. [CrossRef]

83. Chen, Q.F.; Liu, Z.P.; Wang, F.P. Natural sesquiterpenoids as cytotoxic anticancer agents. Mini Rev. Med. Chem. 2011, 11, 1153-1164. [CrossRef]

84. Chen, Z.; Zhong, C. Oxidative stress in Alzheimer's disease. Neurosci. Bull. 2014, 30, 271-281. [CrossRef] [PubMed]

85. Choi, Y.H.; Choi, C.W.; Kim, J.K.; Jeong, W.; Park, G.H.; Hong, S.S. (-)-Pteroside N and pterosinone, new BACE1 and cholinesterase inhibitors from Pteridium aquilinum. Phytochem. Lett. 2018, 27, 63-68. [CrossRef]

86. Jung, H.J.; Min, B.S.; Jung, H.A.; Choi, J.S. Sesquiterpenoids from the heartwood of Juniperus chinensis. Nat. Prod. Sci. 2017, 23, 208-212. [CrossRef]

87. Yang, D.L.; Wang, H.; Guo, Z.K.; Li, W.; Mei, W.L.; Dai, H.F. Fragrant agarofuran and eremophilane sesquiterpenes in agarwood 'Qi-Nan' from Aquilaria sinensis. Phytochem. Lett. 2014, 8, 121-125. [CrossRef]

88. Chen, H.W.; He, X.H.; Yuan, R.; Wei, B.J.; Chen, Z.; Dong, J.X.; Wang, J. Sesquiterpenes and a monoterpenoid with acetylcholinesterase (AchE) inhibitory activity from Valeriana officinalis var. latiofolia in vitro and in vivo. Fitoterapia 2016, 110, 142-149. [CrossRef]

89. Shi, S.H.; Zhao, X.; Liu, B.; Li, H.; Liu, A.J.; Wu, B.; Bi, K.S.; Jia, Y. The effects of sesquiterpenes-rich extract of Alpinia oxyphylla Miq. on amyloid- $\beta$-induced cognitive impairment and neuronal abnormalities in the cortex and hippocampus of mice. Oxidative Med. Cell. Longev. 2014. [CrossRef]

90. Fujiwara, M.; Yagi, N.; Miyazawa, M. Acetylcholinesterase inhibitory activity of volatile oil from Peltophorum dasyrachis Kurz ex Bakar (yellow batai) and bisabolane-type sesquiterpenoids. J. Agric. Food Chem. 2010, 58, 2824-2829. [CrossRef] [PubMed] 
91. Miyazawa, M.; Nakahashi, H.; Usami, A.; Matsuda, N. Chemical composition, aroma evaluation, and inhibitory activity towards acetylcholinesterase of essential oils from Gynura bicolor DC. J. Nat. Med. 2016, 70, 282-289. [CrossRef]

92. Christianah, A.E.; Idowu, O.; Tiwalade, A.O.; Omolara, O.; Armando, M.D. Acetylcholinesterase inhibitory effect and characterization of the essential oil of Plectranthusa egyptiacus (Forssk.) C. Chr. growing in Nigeria. Med. Aromat. Plants 2018, 7, 1000316. [CrossRef]

93. Rahali, N.; Mehdi, S.; Younsi, F.; Boussaid, M.; Messaoud, C. Antioxidant, $\alpha$-amylase, and acetylcholinesterase inhibitory activities of Hertiacheiri folia essential oils: Influence of plant organs and seasonal variation. Int. J. Food Prop. 2017, 20, S1637-S1651. [CrossRef]

94. Tel, G.; Ozturk, M.; Duru, M.E.; Harmandar, M.; Topcu, G. Chemical composition of the essential oil and hexane extract of Salvia chionantha and their antioxidant and anticholinesterase activities. Food Chem. Toxicol. 2010, 48, 3189-3193. [CrossRef] [PubMed]

95. Mukherjee, P.K.; Kumar, V.; Mac, M.; Houghton, P.J. In vitro acetylcholinesterase inhibitory activity of the essential oil from Acorus calamus and its main constituents. Planta Medica 2007, 73, 283-285. [CrossRef]

96. Olawuni, I.J.; Ndoni, S.A.; Esada, E.E.; Bamidele, F.S.; Obuotor, E.M. In vitro anti-cholinesterase and cognitive enhancing properties of essential oils from Piper nigrum L. and Monodora myristica (Gaertn) dunal. Int.J. Pharmacol. Toxicol. 2018, 6, 34-41. [CrossRef]

97. Da Silva Barbosa, D.C.; Holanda, V.N.; Dias De Assis, C.R.; De Oliveira Farias de Aguiar, J.C.R.; do Nascimento, P.H.; da Silva, W.V.; do Amaral Ferraz Navarro, D.M.; da Silva, M.V.; de Menezes Lima, V.L.; dos Santos Correia, M.T. Chemical composition and acetylcholinesterase inhibitory potential, in silico, of Myrciaria floribunda (H. West ex Willd.) O. Berg fruit peel essential oil. Ind. Crops Prod. 2020, 151, 112372. [CrossRef]

98. Liu, Y.; Li, J.; Li, D.; Li, X.M.; Zhou, G.; Xu, K.P.; Kang, F.H.; Zou, Z.X.; Xu, P.S.; Tan, G.S. Anti-cholinesterase activities of constituents isolated from Lycopodiastrum casuarinoides. Fitoterapia 2019, 139, 104366. [CrossRef] [PubMed]

99. Bendjedou, H.; Barboni, L.; Maggi, F.; Bennaceur, M.; Benamar, H. Alkaloids and sesquiterpenes from roots and leaves of Lycium europaeum L. (Solanaceae) with antioxidant and anti-acetylcholinesterase activities. Nat. Prod. Res. 2019, 23. [CrossRef] [PubMed]

100. Shao, H.; Mei, W.L.; Kong, F.D.; Dong, W.H.; Gai, C.J.; Li, W.; Zhu, G.P.; Dai, H.F. Sesquiterpenes of agarwood from Gyrinopssalicifolia. Fitoterapia 2016, 113, 182-187. [CrossRef]

101. Dong, F.W.; Liu, Y.; Wu, Z.K.; Gao, W.; Zi, C.T.; Dan, Y.; Luo, H.R.; Zhou, J.; Hu, J.M. Iridoids and sesquiterpenoids from the roots of Valeriana jatamansi Jones. Fitoterapia 2015, 102, 27-34. [CrossRef] [PubMed]

102. Li, W.; Liao, G.; Dong, W.H.; Kong, F.D.; Wang, P.; Wang, H.; Mei, W.L.; Dai, H.F. Sesquiterpenoids from Chinese agarwood induced by artificial holing. Molecules 2016, 21, 274. [CrossRef]

103. Qin, X.J.; Rauwolf, T.J.; Li, P.P.; Liu, H.; McNeely, J.; Hua, Y.; Liu, H.Y.; Porco, J.A. Isolation and synthesis of novel meroterpenoids from Rhodomyrtus tomentosa: Investigation of a reactive enetrione intermediate. Angewandte Chemie 2019, 58, 4291-4296. [CrossRef] [PubMed]

104. Khan, S.; Khan, H.; Ali, F.; Ali, N.; Khan, F.U.; Khan, S.U. Antioxidant, cholinesterase inhibition activities and essential oil analysis of Nelumbo nucifera seeds. Nat. Prod. Res. 2016, 30, 1335-1338. [CrossRef]

105. Medimagh, S.; Daami-Remadi, M.; Jabnoun-Khiareddine, H.; Jannet, H.B. Chemical composition, antimicrobial and antiacetylcholinesterase activities of essential oils from the Tunisian Asteriscusm aritimes(L.) less. Mediterr. J. Chem. 2012, 2, 459-470. [CrossRef]

106. Zhou, Q.Y.; Yang, X.Q.; Zhang, Z.X.; Wang, B.Y.; Hu, M.; Yang, Y.B.; Zhou, H.; Ding, Z.T. New azaphilones and tremulane sesquiterpene from endophytic Nigrosporaoryzae cocultured with Irpexlacteus. Fitoterapia 2018, 130, 26-30. [CrossRef] [PubMed]

107. Murata, K.; Matsumura, S.; Yoshioka, Y.; Ueno, Y.; Matsuda, H. Screening of $\beta$-secretase and acetylcholinesterase inhibitors from plant resources. J. Nat. Med. 2015, 69, 123-129. [CrossRef] [PubMed]

108. Miri, A.; Sharifi-Rad, J. Guaiasistanol: A new guaiane sesquiterpenoid from Teucrium persicum Boiss. Cell. Mol. Biol. 2015, 61, 64-67.

109. Ma, Q.Y.; Chen, Y.C.; Huang, S.Z.; Guo, Z.K.; Dai, H.F.; Hua, Y.; Zhao, Y.X. Two new guaiane sesquiterpenoids from Daphne holosericea (Diels) Hamaya. Molecules 2014, 19, 14266-14272. [CrossRef] [PubMed]

110. Li, W.; Cai, C.H.; Guo, Z.K.; Wang, H.; Zuo, W.J.; Dong, W.H.; Mei, W.L.; Dai, H.F. Five new eudesmane-type sesquiterpenoids from Chinese agarwood induced by artificial holing. Fitoterapia 2015, 100, 44-49. [CrossRef] [PubMed]

111. Wong, K.C.; Hamid, A.; Eldeen, I.M.S.; Asmawi, M.Z.; Baharuddin, S.; Abdillahi, H.S.; Staden, J.V. A new sesquiterpenoid from the rhizomes of Homalomenasagittifolia. Nat. Prod. Res. 2012, 26, 850-858. [CrossRef] [PubMed]

112. Wang, P.C.; Ran, X.H.; Chen, R.; Luo, H.R.; Ma, Q.Y.; Liu, Y.Q.; Hu, J.M.; Huang, S.Z.; Jiang, H.Z.; Chen, Z.Q.; et al. Sesquiterpenoids and lignans from the roots of Valeriana officinalis L. Chem. Biodivers. 2011, 8, 1908-1913. [CrossRef] [PubMed]

113. Zhang, J.; Fan, P.; Zhu, R.; Li, R.; Lin, Z.; Sun, B.; Zhang, C.; Zhou, J.; Lou, H. Marsupellins A-F, ent-longipinane-type sesquiterpenoids from the Chinese liverwort Marsupella alpine with acetylcholinesterase inhibitory activity. J. Nat. Prod. 2014, 77, 1031-1036. [CrossRef]

114. Misra, B.B.; Dey, S. TLC-bioautographic evaluation of in vitro anti-tyrosinase and anti-cholinesterase potentials of sandalwood oil. Nat. Prod. Commun. 2013, 8. [CrossRef]

115. Arruda, M.; Viana, H.; Rainha, N.; Neng, N.R.; Rosa, J.S.; Nogueira, J.M.; Barreto, M.D.C. Anti-acetylcholinesterase and antioxidant activity of essential oils from Hedychium gardnerianum Sheppard ex Ker-Gawl. Molecules 2012, 17, $3082-3092$. [CrossRef] 
116. Rasul, A.; Parveen, S.; Ma, T. Costunolide: A novel anticancer sesquiterpene lactone. Bangladesh J. Pharmacol. 2012, 7, 6-13. [CrossRef]

117. Matejic, J.; Sarac, Z.; Randelovic, V. Pharmacological activity of sesquiterpene lactones. Biotechnol. Biotechnol. Equip. 2010, 24, 95-100. [CrossRef]

118. Leitolis, A.; Amoah, S.K.; Biavatti, M.W.; da Silva-Santos, J.E. Sesquiterpene lactones from Hedyosmumbrasiliense induce in vitro relaxation of rat aorta and corpus cavernosum. Revista Brasileira de Farmacognosia 2016, 26, 363-368. [CrossRef]

119. Ferrari, F.C.; Ferreira, L.C.; Souza, M.R.; Grabe-Guimaraes, A.; Paula, C.A.; Rezende, S.A.; Saude-Guimaraes, D.A. Antiinflammatory sesquiterpene lactones from Lychnophoratrichocarpha Spreng. (Brazilian Arnica). Phytother. Res. 2013, 27, 384-389. [CrossRef]

120. Tholl, D. Biosynthesis and biological functions of terpenoids in plants. Adv. Biochem. Eng. Biotechnol. 2015, 148, 63-106. [CrossRef]

121. Elsebaia, M.F.; Ghabbourb, H.A.; Marzouka, A.M.; Salmasd, R.E.; Orhane, I.E.; Senole, F.S. Amberboin and lipidiol: X-ray crystalographic data, absolute configuration and inhibition of cholinesterase. Phytochem. Lett. 2018, 27, 44-48. [CrossRef]

122. Hegazy, M.E.; Ibrahim, A.Y.; Mohamed, T.A.; Shahat, A.A.; EI-Halawany, A.M.; Abdel-Azim, N.S.; Alsaid, M.S.; Par, W.P.W Sesquiterpene lactones from Cynara cornigera: Acetyl cholinesterase inhibition and in silico ligand docking. Planta Medica 2016, 82, 138-146. [CrossRef]

123. Hajimehdipoor, H.; Mosaddegh, M.; Naghibi, F.; Haeri, A.; Hamzeloo-Moghadam, M. Natural sesquiterpene lactones as acetylcholinesterase inhibitors. Anais da Academia Brasileira de Ciências 2014, 86, 801-805. [CrossRef]

124. Ibrahim, M.; Farooq, T.; Hussain, N.; Hussain, A.; Gulzar, T.; Hussain, I.; Akash, M.S.; Rehmani, F.S. Acetyl and butyryl cholinesterase inhibitory sesquiterpene lactones from Amberboaramosa. Chem. Cent. J. 2013, 7, 116. [CrossRef] [PubMed]

125. Patel, M.B.; Amin, D. Sphaeranthus indicus flower derived constituents exhibits synergistic effect against acetylcholinesterase and possess potential antiamnestic activity. J. Complement. Integr. Med. 2012, 9. [CrossRef] [PubMed]

126. Marchi, A.; Appendino, G.; Pirisi, I.; Ballero, M.; Loi, M.C. Genetic differentiation of two distinct chemotypes of Ferulacommunis (Apiaceae) in Sardinia (Italy). Biochem. Sys. Eco. 2003, 31, 1397-1408. [CrossRef]

127. Iranshahi, M.; Rezaee, R.; Sahebkar, A.; Bassarello, C.; Piacente, S.; Pizza, C. Sesquiterpene coumarins from the fruits of Ferulabadrakema. Pharm. Biol. 2009, 47, 344-347. [CrossRef]

128. Guangzhi, L.; Junchi, W.; Xiaojin, L.; Li, C.; Na, L.; Gang, C.; Jun, Z.; Jianyong, S. Two new sesquiterpene coumarins from the seeds of Ferulasinkiangensis. Phytochem. Lett. 2015, 13, 123-126. [CrossRef]

129. Guvenalp, Z.; Özbek, H.; Yerdelen, K.Ö.; Yılmaz, G.; Kazaz, C.; Demirezer, L.O. Cholinesterase inhibition and molecular docking studies of sesquiterpene coumarin ethers from Heptapteracilicica. Rec. Nat. Prod. 2017, 1, 462-467. [CrossRef]

130. Torres-Romero, D.; Jiménez, I.A.; Rojas, R.; Robert, H.; López, G.M.; Bazzocchi, I.L. Dihydro- $\beta$-agarofuran sesquiterpenes isolated from Celastrusvulcanicola as potential anti-Mycobacterium tuberculosis multidrug-resistant agents. Bioorg. Med. Chem. 2011, 19, 2182-2189. [CrossRef] [PubMed]

131. Alarcon, J.; Cespedes, C.L.; Muñoz, E.; Balbontin, C.; Valdes, F.; Gutierrez, M.; Luis, A.; Seigler, D.S. Dihydroagarofuranoid sesquiterpenes as cetylcholinesterase inhibitors from Celastraceae plants: Maytenusdisticha and Euonymus japonicas. J. Agric. Food. Chem. 2015, 63, 10250-10256. [CrossRef]

132. Alarcón, J.; Astudillo, L.; Gutierrez, M. Inhibition of acetylcholinesterase activity by dihydro- $\beta$-agarofuran sesquiterpenes isolated from Chilean Celastraceae. Zeitschriftfür Naturforschung 2008, 63, 853-856. [CrossRef] [PubMed]

133. Gul, A.; Bakht, J.; Mehmood, F. Huperzine: A response to cognitive impairment and task switching deficits in patients with Alzheimer's disease. J. Chin. Med. Assoc. 2019, 82, 40-43. [CrossRef] [PubMed]

134. Wang, R.; Yan, H.; Tang, X.C. Progress in studies of huperzine A, a natural cholinesterase inhibitor from Chinese herbal medicine. Acta. Pharmacol. Sin. 2006, 27, 1-26. [CrossRef] [PubMed]

135. Wang, L.S.; Zhou, J.; Shao, X.M.; Tang, X.C. Huperzine A attenuates cognitive deficits and brain injury in neonatal rats after hypoxia ischemia. Brain Res. 2002, 949, 62-70. [CrossRef]

136. Kumar, G.P.; Anilakumar, K.R.; Naveen, S. Phytochemicals having neuroprotective properties from dietary sources and medicinal herbs. Pharmacogn. J. 2015, 7. [CrossRef]

137. Zhang, H.Y.; Tang, X.C. Neuroprotective effects of huperzine A: New therapeutic targets for neurodegenerative disease. Trends Pharmacol. Sci. 2006, 27, 619-625. [CrossRef] [PubMed]

138. Qi, X.L.; Zhao, P.; Zhang, Y.Y.; Bai, M.; Lin, B.; Huang, X.X.; Song, S.J. Sesquiterpenes from stigma maydis (Zea mays) as a crop by-product \& their potential neuroprotection and inhibitory activities of A $\beta$ aggregation. Ind. Crops Prod. 2018, 121, 411-417. [CrossRef]

139. Huanga, S.H.; Dukea, R.D.; Chebibb, M.; Sasakic, K.; Wada, K.; Johnston, G.A. Bilobalide, a sesquiterpene trilactone from Ginkgo biloba, is an antagonist at recombinant $\alpha_{1} \beta_{2} \mathrm{Y}_{2 \mathrm{~L}} \mathrm{GABA}_{\mathrm{A}}$ receptors. Eur. J. Pharmacol. 2003, 464, 1-8. [CrossRef]

140. Amoah, S.K.; DallaVecchia, M.T.; Pedrini, B.; Carnhelutti, G.L.; Gonçalves, A.E.; Dos Santos, D.A.; Biavatti, M.W.; De Souza, M.M. Inhibitory effect of sesquiterpene lactones and these squiterpene alcohol aromadendrane- $4 \beta, 10 \alpha$-diol on memory impairment in a mouse model of Alzheimer. Eur. J. Pharmacol. 2015, 769, 195-202. [CrossRef] [PubMed]

141. Shi, Z.M.; Han, Y.W.; Han, X.H.; Zhang, K.; Chang, Y.N.; Hu, Z.M.; Qi, H.X.; Ting, C.; Zhen, Z.; Hong, W. Upstream regulators and downstream effectors of NF-kB in Alzheimer's disease. J. Neurol. Sci. 2016, 366, 127-134. [CrossRef] [PubMed]

142. Srinivasan, M.; Lahiri, D.K. Significance of NF-kB as a pivotal therapeutic target in the neurodegenerative pathologies of Alzheimer's disease and multiple sclerosis. Expert Opin. Ther. Targets 2015, 19, 471-487. [CrossRef] 
143. Wanga, Y.; Wang, M.; Xua, M.; Li, T.; Fan, K.; Yan, T.; Xiao, F.; Bi, K.; Jia, Y. Nootkatone, a neuroprotective agent from AlpiniaeOxyphyllae Fructus, improves cognitive impairment in lipopolysaccharide-induced mouse model of Alzheimer's disease. Int. Immunopharmacol. 2018, 62, 77-85. [CrossRef] [PubMed]

144. Khalil, M.N.; Choucry, M.A.; El Senousy, A.S.; Hassan, A.; El-Marasy, S.A.; El Awdan, S.A.; Omar, F.A. Ambrosin, a potent NF- $\beta$ inhibitor, ameliorates lipopolysaccharide induced memory impairment, comparison to curcumin. PLoS ONE 2019, 14, e0219378. [CrossRef]

145. Balmus, I.M.; Ciobica, A. Main plant extracts'active properties effective on scopolamine-induced memory loss. Am. J. Alzheimers Dis. Dement. 2017, 32, 418-428. [CrossRef] [PubMed]

146. Joshi, H.; Parle, M. Nardostachysjatamansi improves learning and memory in mice. J. Med. Food 2006, 9, 113-118. [CrossRef]

147. Huang, L.K.; Chao, S.P.; Hu, C.J. Clinical trials of new drugs for Alzheimer disease. J. Biomed. Sci. 2020, 27. [CrossRef]

148. Cummings, J.; Lee, G.; Ritter, A.; Zhong, K. Alzheimer's disease drug development pipeline: 2018. Alzheimers Dement. Transl. Res. Clin. Interv. 2018, 4, 195-214. [CrossRef] [PubMed]

149. Rhee, I.K.; Van Rijn, R.M.; Verpoorte, R. Qualitative determination of false-positive effects in the acetylcholinesterase assay using thin layer chromatography. Phytochem. Anal. 2003, 14, 127-131. [CrossRef]

150. Selkoe, D.J. The cell biology of $\beta$-amyloid precursor protein and presenilin in Alzheimer's disease. Trends Cell Biol. 1998, 8 , 447-453. [CrossRef]

151. Hu, J.; Liu, C.C.; Chen, X.F.; Zhang, Y.W.; Xu, H.; Bu, G. Opposing effects of viral mediated brain expression of apolipoprotein E2 (apoE2) and apoE4 on apoElipidation and A $\beta$ metabolism in apoE4- targeted replacement mice. Mol. Neurodegener. 2015, 10. [CrossRef]

152. Stancu, I.C.; Vasconcelos, B.; Terwel, D.; Dewachter, I. Models of $\beta$-amyloid induced Tau-pathology: The long and "folded" road to understand the mechanism. Mol. Neurodegener. 2014, 9. [CrossRef]

153. Veber, D.F.; Johnson, S.R.; Cheng, H.Y.; Smith, B.R.; Ward, K.W.; Kopple, K.D. Molecular properties that influence the oral bioavailability of drug candidates. J. Med. Chem. 2002, 45, 2615-2623. [CrossRef] [PubMed]

154. Blanco-Silvente, L.; Castells, X.; Saez, M.; Barcelo, M.A.; Garre-Olmo, J.; Vilalta-Franch, J. Discontinuation, efficacy, and safety of cholinesterase inhibitors for Alzheimer's disease: A meta-analysis and metaregression of 43 randomized clinical trials enrolling 16106 patients. Int. J. Neuropsychopharmacol. 2017, 20, 519-528. [CrossRef]

155. Kehrer, C.; Maziashvili, N.; Dugladze, T.; Gloveli, T. Altered excitatory-inhibitory balance in the NMDA-hypofunction model of schizophrenia. Front. Mol. Neurosci. 2008, 1. [CrossRef] [PubMed]

156. Cummings, D.M.; André, V.M.; Uzgil, B.O.; Gee, S.M.; Fisher, Y.E.; Cepeda, C. Alterations in cortical excitation and inhibition in genetic mouse models of Huntington's disease. J. Neurosci. 2009, 29, 10371-10386. [CrossRef]

157. Sun, B.; Halabisky, B.; Zhou, Y.; Palop, J.J.; Yu, G.; Mucke, L.; Gan, L. Imbalance between GABAergic and glutamatergic transmission impairs adult neurogenesis in an animal model of Alzheimer's disease. Cell Stem Cell 2009, 5, 624-633. [CrossRef]

158. Gueli, M.C.; Taibi, G. Alzheimer's disease: Amino acid levels and brain metabolic status. Neurol. Sci. 2013, 34, 1575-1579. [CrossRef] [PubMed]

159. Zhan, X.Q.; Yao, J.J.; Liu, D.D.; Ma, Q.; Mei, Y.A. A $\beta 40$ modulates GABAA receptor $\alpha 6$ subunit expression and rat cerebellar granule neuron maturation through the ERK/mTOR pathway. J. Neurochem. 2014, 128, 350-362. [CrossRef]

160. Schweizer, C.; Balsiger, S.; Bluethmann, H.; Mansuy, I.M.; Fritschy, J.M.; Mohler, H.; Lüscher, B. The $\gamma 2$ subunit of GABAA receptors is required for maintenance of receptors at mature synapses. Mol. Cell. Neurosci. 2003, 24, 442-450. [CrossRef]

161. Palop, J.J.; Chin, J.; Roberson, E.D.; Wang, J.; Thwin, M.T.; Bien-Ly, N.; Yoo, J.; Ho, K.O.; Yu, G.Q.; Kreitzer, A.; et al. Aberrant excitatory neuronal activity and compensatory remodeling of inhibitory hippocampal circuits in mouse models of Alzheimer's disease. Neuron 2007, 55, 697-711. [CrossRef] [PubMed]

162. Mehmet, E.A.; Hasan, T.; Adil, M. In vitro neuroprotective effects of farnesene sesquiterpene on Alzheimer's disease model of differentiated neuroblastoma cell line. Int. J. Neurosci. 2020, 1-10. [CrossRef]

163. Karunaweera, N.; Raju, R.; Gyengesi, E.; Münch, G. Plant polyphenols as inhibitors of NF-кB induced cytokine production-A potential anti-inflammatory treatment for Alzheimer's disease? Front. Mol. Neurosci. 2015, 8, 24. [CrossRef]

164. Van Eldik, L.J.; Carrillo, M.C.; Cole, P.E.; Feuerbach, D.; Greenberg, B.D.; Hendrix, J.A.; Kennedy, M.; Kozauer, N.; Margolin, R.A.; Molinuevo, J.L.; et al. The roles of inflammation and immune mechanisms in Alzheimer's disease. Alzheimers Dement. Transl. Res. Clin. Interv. 2016, 2, 99-109. [CrossRef] [PubMed] 